\title{
Influence of zinc sulphate on the corrosion resistance of L80 alloy immersed in sea water in the absence and presence of sodium potassium tartrate and trisodium citrate
}

\author{
A. Grace Baby, ${ }^{1}$ S. Rajendran, ${ }^{2 *}$ V. Johnsirani, ${ }^{1}$ A. Al-Hashem, ${ }^{3}$ \\ N. Karthiga ${ }^{2}$ and P. Nivetha ${ }^{4}$ \\ ${ }^{1} P G$ Department of Chemistry, Sakthi College of Arts and Science for Women, \\ Oddanchatram-624 619, India \\ ${ }^{2}$ Corrosion Research Centre, Department of Chemistry, St Antony's College of Arts and \\ Science for Women, Dindigul 62405, India \\ ${ }^{3}$ Petroleum Research Centre, Kuwait Institute for Scientific Research, Kuwait \\ ${ }^{4}$ Department of Chemistry, Thiravium College of Arts and Science, Periyakulam - \\ Cumbum Road, Kailasapatty, Tamil Nadu 625605, India \\ *E-mail: susairajendran@gmail.com
}

\begin{abstract}
Seawater can be used in cooling water systems. L80 can be used as pipeline carrying sea water. However, this alloy will undergo corrosion. Corrosion can be prevented by addition of inhibitors such as sodium potassium tartrate (SPT), trisodium citrate (TSC), and zinc sulphate. Corrosion resistance of L80 alloy in sea water in the absence and presence of the above inhibitors has been evaluated by polarisation study and AC impedance spectra. It is observed that SPT and TSC show better inhibition efficiency in the presence of $\mathrm{Zn}^{2+}$. Further it is found that SPT-Zn system is better than the TSC-Zn system. When the SPT or TSC inhibitor is added to sea water, a protective film is formed on the metal surface. This prevents the transfer or release of electrons from the metal surface to the bulk of the solution. Thus corrosion is controlled. This is revealed by the fact that, during polarisation study, the linear polarisation resistance value increases and corrosion current value decreases. During electrochemical impedance study, charge transfer value increases and double layer capacitance value decreases. In the presence of $\mathrm{Zn}^{2+}$, corrosion resistance of the metal further increases, which is supported by the fact that the linear polarisation resistance value further increases and corrosion current value further decreases. Similarly during electrochemical impedance study, the charge transfer resistance increases tremendously and the double layer capacitance value decreases to a great extent. It is inferred that in the presence of $\mathrm{Zn}^{2+}$, more inhibitor is transported towards the metal surface as a $\mathrm{Zn}^{2+}$ inhibitor complex. On the metal surface, an iron inhibitor complex is formed on the anodic sites of the metal surface and $\mathrm{Zn}^{2+}$ is released. The released $\mathrm{Zn}^{2+}$ combines with $\mathrm{OH}^{-}$to form $\mathrm{Zn}(\mathrm{OH})_{2}$ on the cathodic sites of the metal surface. Thus in the presence of $\mathrm{Zn}^{2+}$, both anodic reaction and cathodic reaction are controlled effectively. This accounts for the increase in corrosion resistance of metal in sea water in the presence of inhibitor and $\mathrm{Zn}^{2+}$.
\end{abstract}


Keywords: corrosion inhibition, seawater, sodium potassium tartrate, trisodium citrate, polarisation study, AC impedance spectra, L80 alloy.

Received: June 25, 2020. Published: August 10, 2020

doi: $\underline{10.17675 / 2305-6894-2020-9-3-12}$

\section{Introduction}

Seawater makes up the oceans and seas, covering more than 70 percent of Earth's surface. Seawater is a complex mixture of 96.5 percent water, 2.5 percent salts, and smaller amounts of other substances, including dissolved inorganic and organic materials, particulates, and a few atmospheric gases [1]. Almost anything can be found in seawater. This includes dissolved materials from Earth's crust as well as materials released from organisms. The most important components of seawater that influence life forms are salinity, temperature, dissolved gases (mostly oxygen and carbon dioxide) and nutrients [2].

Seawater can be used in cooling water systems, especially in ships and in marine environments. In these systems L80 alloy can be used to carry out the seawater. Hence knowledge of corrosion resistance of L80 alloy in seawater in presence of inhibitors will be useful. Corrosion resistance of aluminium and its alloys [3, 4], zinc and its alloys [5, 6], copper and its alloys [7, 8], mild steel [9, 10], stainless steel [11, 12], nickel and its alloys $[13,14]$ in seawater has been evaluated. Corrosion inhibitors such as, inorganic compounds $[15,16]$ and natural products $[17,18]$ have been used to prevent the corrosion of metals and alloys. In the present study corrosion resistance of L80 alloy in seawater in presence of sodium potassium tartrate (SPT) and trisodium citrate (TSC) has been evaluated by electrochemical studies such as polarization study and AC impedance spectra. Influence of $\mathrm{Zn}^{2+}$ on the corrosion resistance of the above systems has also been evaluated.

\section{Experimental}

\section{Electrochemical studies}

In the present work corrosion resistance of L80 alloy immersed in various test solutions were measured by polarization study and AC impedance spectra.

\section{Polarization study}

In the present study polarization studies were carried out in a CHI Electrochemical work station/analyzer, model 660A. It was provided with automatic IR compensation facility. A three electrode cell assembly was used (Figure 1).

The working electrode was L80 alloy. A SCE was the reference electrode. Platinum was the counter electrode. A time interval of 5 to $10 \mathrm{~min}$ was given for the system to attain a steady state open circuit potential. The working electrode and the platinum electrode were immersed in sea water in the absence and presence of inhibitor. Saturated calomel electrode was connected with the test solution through a salt bridge. From polarization study, corrosion parameters such as corrosion potential $\left(E_{\text {corr }}\right)$, corrosion current $\left(I_{\text {corr }}\right)$, Tafel slopes anodic $=$ 
$b_{\mathrm{a}}$ and cathodic $=b_{\mathrm{c}}$ and $L P R$ (linear polarisation resistance) value were determined. The scan rate was $0.01 \mathrm{~V} / \mathrm{s}$. The hold time at $\left(E_{\mathrm{fcs}}\right)$ was zero and the quiet time was 2 seconds.

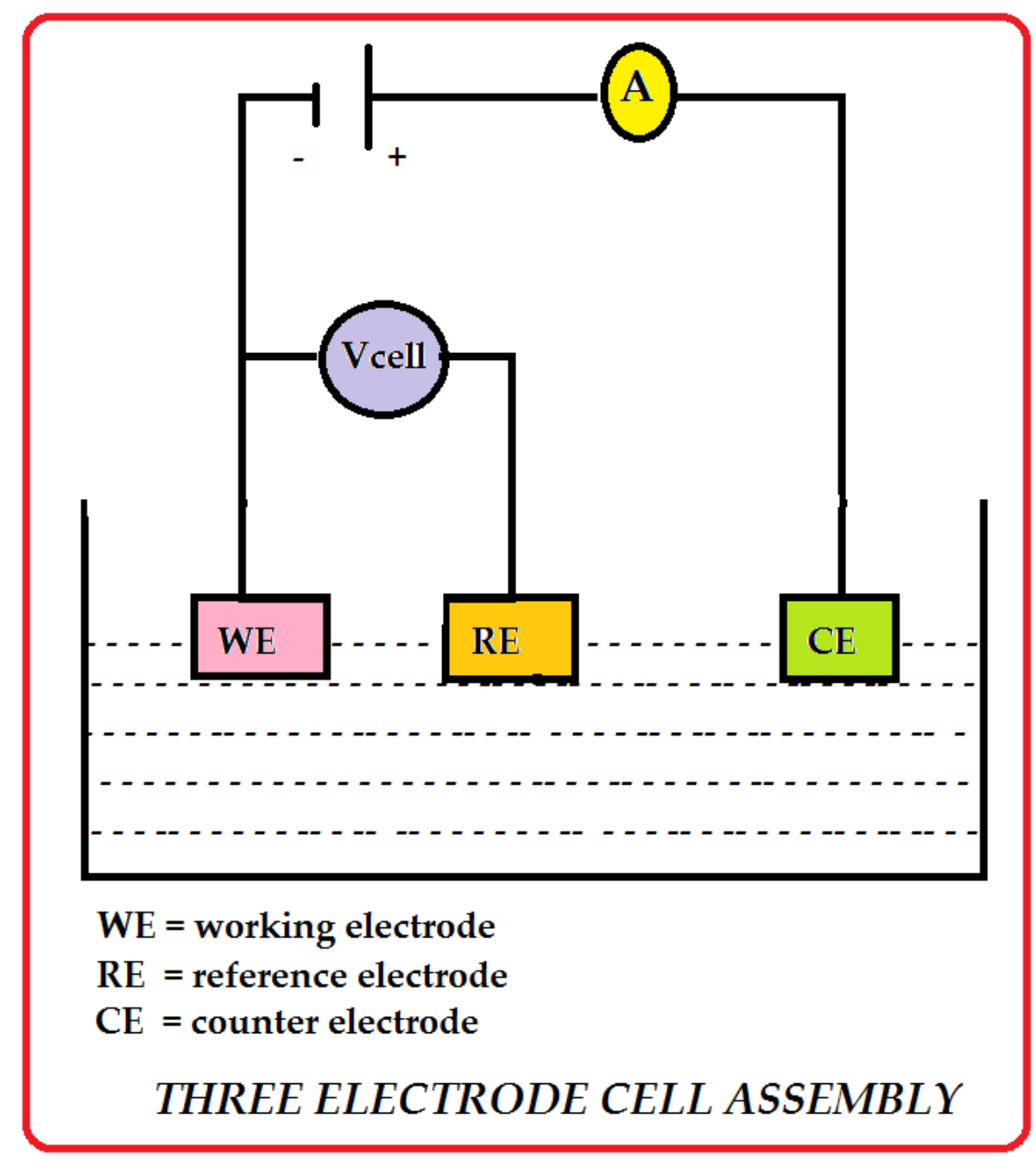

Figure 1. Three electrode cell assembly.

\section{AC Impedance spectra}

In the present investigation the same instrument and set-up used for polarization study was used to record $\mathrm{AC}$ impedance spectra also. A time interval of 5 to 10 min was given for the system to attain a steady state open circuit potential. The real part $\left(Z^{\prime}\right)$ and imaginary part $\left(Z^{\prime \prime}\right)$ of the cell impedance were measured in ohms at various frequencies. AC impedance spectra were recorded with initial $E(\mathrm{~V})=0$, high frequency $\left(\mathrm{Hz}=1 \cdot 10^{5}\right)$, low frequency $(\mathrm{Hz}=1)$, amplitude $(\mathrm{V})=0.005$ and quiet time $(\mathrm{s})=2$. From Nyquist plot the values of charge transfer resistance $\left(R_{\mathrm{t}}\right)$ and the double layer capacitance $\left(C_{\mathrm{dl}}\right)$ were calculated.

$$
R_{\mathrm{t}}=\left(R_{\mathrm{s}}+R_{\mathrm{t}}\right)-R_{\mathrm{s}}
$$

Where $R_{\mathrm{s}}=$ solution resistance. 
$C_{\mathrm{dl}}$ values were calculated using the relationship

$$
C_{\mathrm{dl}}=1 / 2 \cdot 3.14 \cdot R_{\mathrm{t}} \cdot f_{\text {max }}
$$

Where $f_{\max }=$ frequency at maximum imaginary impedance.

Sea water

The composition of sea water used in this study is given in Table 1. Sea water was collected in Bay of Bengal, located at Kanampadi, East Coast Road, Chennai, India.

Table 1. Composition of sea water.

\begin{tabular}{|c|c|c|c|}
\hline Physical Examination & Acceptable Limit & Permissible limit & Sample Value \\
\hline 1. Colour & - & - & Colourless \& Clear \\
\hline 2. Odour & Unobjectionable & & Unobjectionable \\
\hline 3. Turbidity NT Units & 1 & 5 & 0.2 \\
\hline 4. Total dissolved solids $\mathrm{mg} / \mathrm{L}$ & 500 & 2000 & 29400 \\
\hline $\begin{array}{l}\text { 5. Electrical conductivity } \\
\mu \mathrm{Ohm}^{-1} / \mathrm{cm}\end{array}$ & - & - & 42000 \\
\hline Chemical Examination & Acceptable Limit & Permissible limit & Sample Value \\
\hline 6. $\mathrm{pH}$ & $6.5-8.5$ & $6.5-8.5$ & 7.46 \\
\hline 7. $\mathrm{pH}$ Alkalinity as $\mathrm{CaCO}_{3}$ & - & 0 & 0 \\
\hline 8. Total alkalinity as $\mathrm{CaCO}_{3}$ & 200 & 600 & 140 \\
\hline 9. Total hardness as $\mathrm{CaCO}_{3}$ & 200 & 600 & 4000 \\
\hline 10. Calcium as $\mathrm{Ca}$ & 75 & 200 & 1200 \\
\hline 11. Magnesium as $\mathrm{Mg}$ & 30 & 100 & 240 \\
\hline 12. Iron as Fe & 0.1 & 1 & 0 \\
\hline 13. Manganese as Mn & 0.1 & 0.3 & NT \\
\hline 14. Free ammonia as $\mathrm{NH}_{3}$ & 0.5 & 0.5 & 0.48 \\
\hline 15. Nitrite as $\mathrm{NO}_{2}$ & 0.5 & 0.5 & 0.104 \\
\hline 16. Nitrate as $\mathrm{NO}_{3}$ & 45 & 45 & 25 \\
\hline 17. Chloride as $\mathrm{Cl}$ & 250 & 1000 & 15000 \\
\hline 18. Fluoride as F & 1 & 1.5 & 1.8 \\
\hline 19. Sulphate as $\mathrm{SO}_{4}$ & 200 & 400 & 1170 \\
\hline 20. Phosphate as $\mathrm{PO}_{4}$ & 0.5 & 0.5 & 1.47 \\
\hline 21. Tids test $4 \mathrm{hrs}$ as $\mathrm{O}_{2}$ & - & - & NT \\
\hline
\end{tabular}




\section{L80 Alloy}

Manufactured to API specification 5CT. This is a controlled yield strength material with a hardness testing requirement. L80 is usually used in wells with sour (hydrogen sulfide) environments. Chemical composition of L80 alloy is given in Table 2.

Table 2. Chemical composition of L80 alloy.

\begin{tabular}{ccccccccccccc}
\hline & $\mathbf{C}$ & $\mathbf{M n}$ & $\mathbf{M o}$ & $\mathbf{C r}$ & $\mathbf{N i}$ & $\mathbf{C u}$ & $\mathbf{T i}$ & $\mathbf{P}$ & $\mathbf{S}$ & $\mathbf{S i}$ & $\mathbf{V}$ & $\mathbf{A l}$ \\
\hline Min & - & - & - & - & - & - & - & - & - & - & - & - \\
$\operatorname{Max}$ & 0.430 & 1.900 & - & - & 0.250 & 0.350 & - & 0.030 & 0.030 & 0.450 & - & - \\
\hline
\end{tabular}

The remaining $W t \%$ was iron.

\section{Inhibitors used}

Pure samples of sodium potassium tartrate (SPT), trisodium citrate (TSC) and zinc sulphate were used as corrosion inhibitors.

\section{Results and Discussion}

\section{Electrochemical studies}

In the present work corrosion resistance of L80 alloy immersed in various test solutions were measured by polarization study and AC impedance spectra.

L80 alloy-sodium potassium tartrate (SPT) system

\section{Polarization study}

The polarization parameters are given in Table 3 . The polarization curves are shown in Figures 2-4. It is seen from Table 3 that when SPT is added to sea water, the corrosion resistance of L80 alloy increases. This is revealed by the fact that when SPT is added to sea water, the $L P R$ values increases and $I_{\text {corr }}$ value decreases (Figures 2-5).

Table 3. Corrosion parameters of L 80 alloy immersed in sea water in the absence and presence of SPT and zinc sulphate $\left(\mathrm{ZnSO}_{4} \cdot 7 \mathrm{H}_{2} \mathrm{O}\right)$ obtained by polarization study.

\begin{tabular}{cccccc}
\hline System & $\begin{array}{c}\boldsymbol{E}_{\text {corr }} \\
\mathbf{m V} \text { sCE }\end{array}$ & $\begin{array}{c}\boldsymbol{b}_{\mathbf{c}} \\
\mathbf{m V} / \mathbf{d e c a d e}\end{array}$ & $\begin{array}{c}\boldsymbol{b}_{\mathbf{a}} \\
\mathbf{m V / d e c a d e}\end{array}$ & $\begin{array}{c}\mathbf{L P R} \\
\mathbf{O h m} \cdot \mathbf{c m}^{\mathbf{2}}\end{array}$ & $\begin{array}{c}\boldsymbol{I}_{\mathbf{c o r r}} \\
\mathbf{A} / \mathbf{c m}^{2}\end{array}$ \\
\hline Sea water & -830 & 161 & 221 & 355 & $1.138 \cdot 10^{-4}$ \\
$\begin{array}{c}\text { Sea water+ SPT (300 ppm) } \\
\begin{array}{c}\text { Sea water+SPT (300 ppm) } \\
+ \text { ZnSO }\end{array}\end{array}$ & -822 & 119 & 212 & 677 & $4.908 \cdot 10^{-5}$ \\
\hline
\end{tabular}




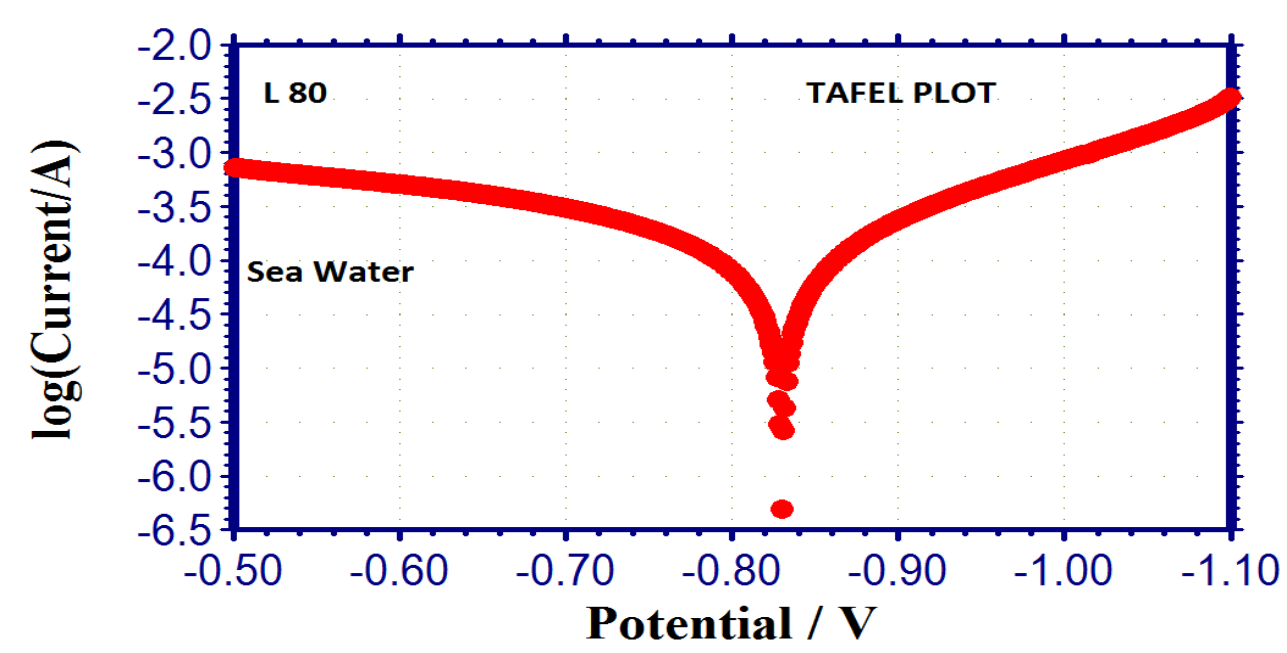

Figure 2. Polarisation curve of L80 alloy immersed in sea water.

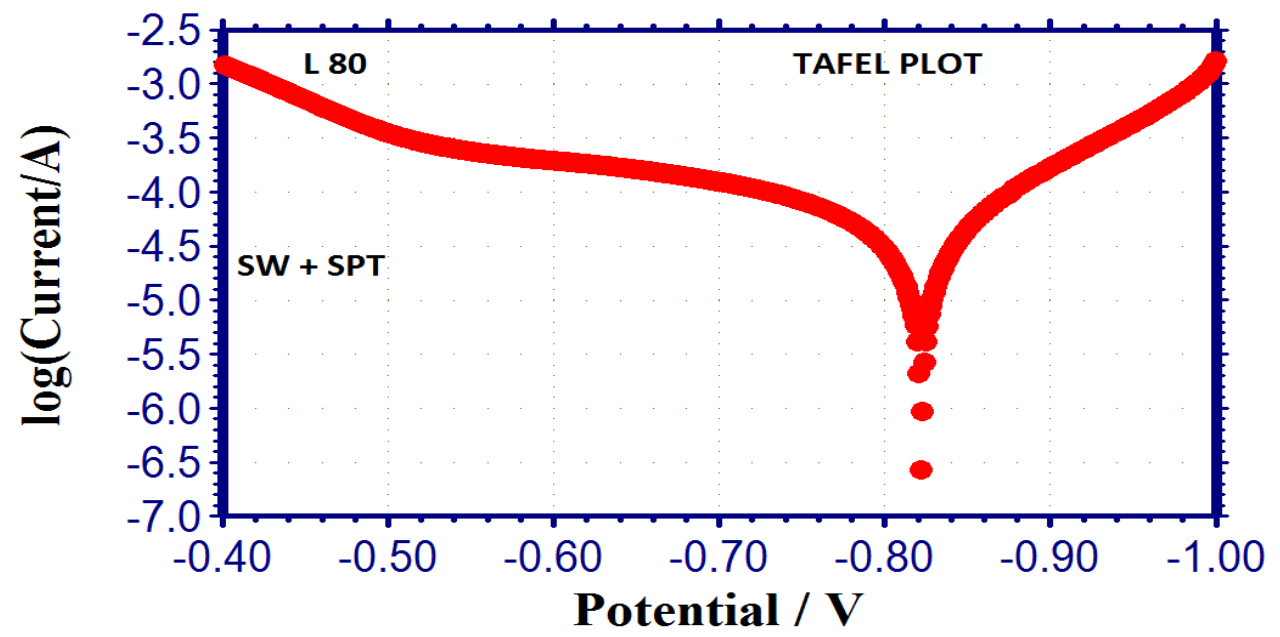

Figure 3. Polarisation curve of L80 alloy immersed in sea water + SPT.

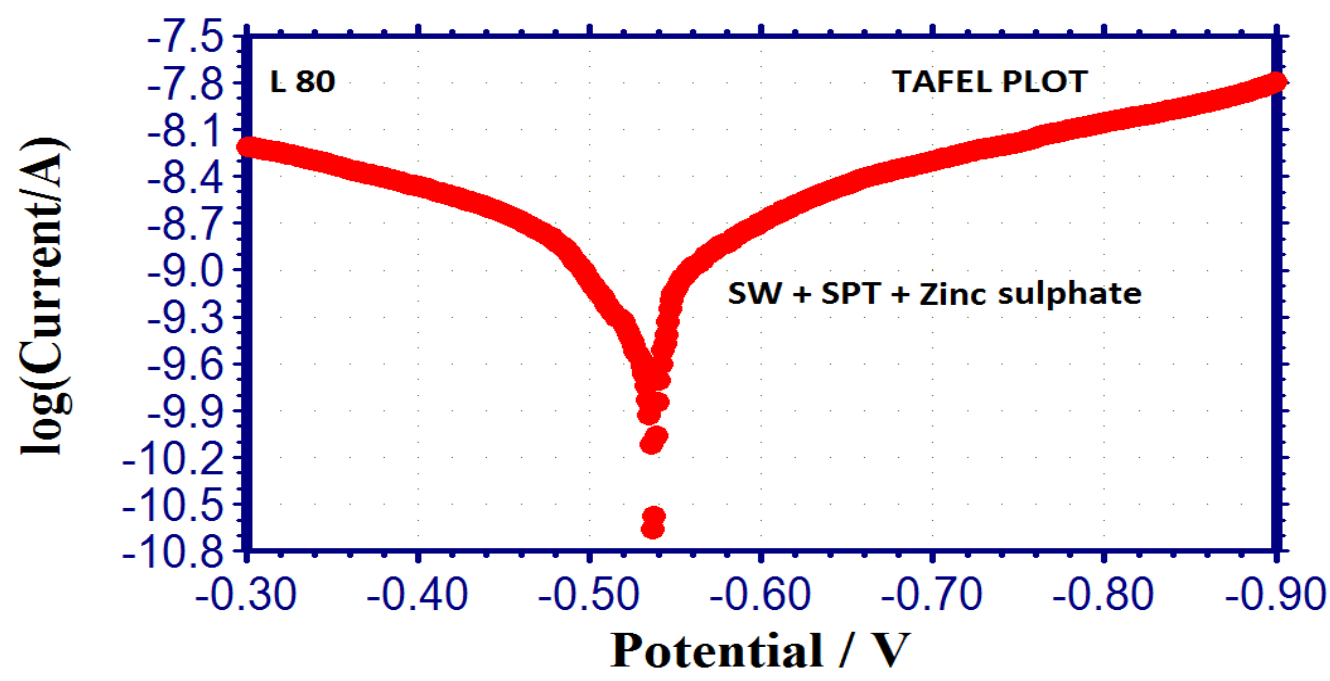

Figure 4. Polarisation curve of L80 alloy immersed in sea water + SPT + zinc sulphate. 
Influence of zinc sulphate $\left(\mathrm{ZnSO}_{4} \cdot 7 \mathrm{H}_{2} \mathrm{O}\right)$

When $\mathrm{ZnSO}_{4} \cdot 7 \mathrm{H}_{2} \mathrm{O}$ is added to the above system, the $L P R$ value increases tremendously to a very great extent Figure 5 and the $I_{\text {corr }}$ decreases very much. This indicates that in presence of SPT $-\mathrm{ZnSO}_{4} \cdot 7 \mathrm{H}_{2} \mathrm{O}$ system the corrosion resistance of $\mathrm{L} 80$ alloy in sea water increases to a great extent. A protective film is formed on the metal surface. This protective film is compact and very stable. This prevents transfer of electrons from anodic site to cathodic site. Hence $L P R$ value increases which results in decrease in corrosion current value. In addition a synergistic effect exists between SPT and $\mathrm{Zn}^{2+}$ ions.

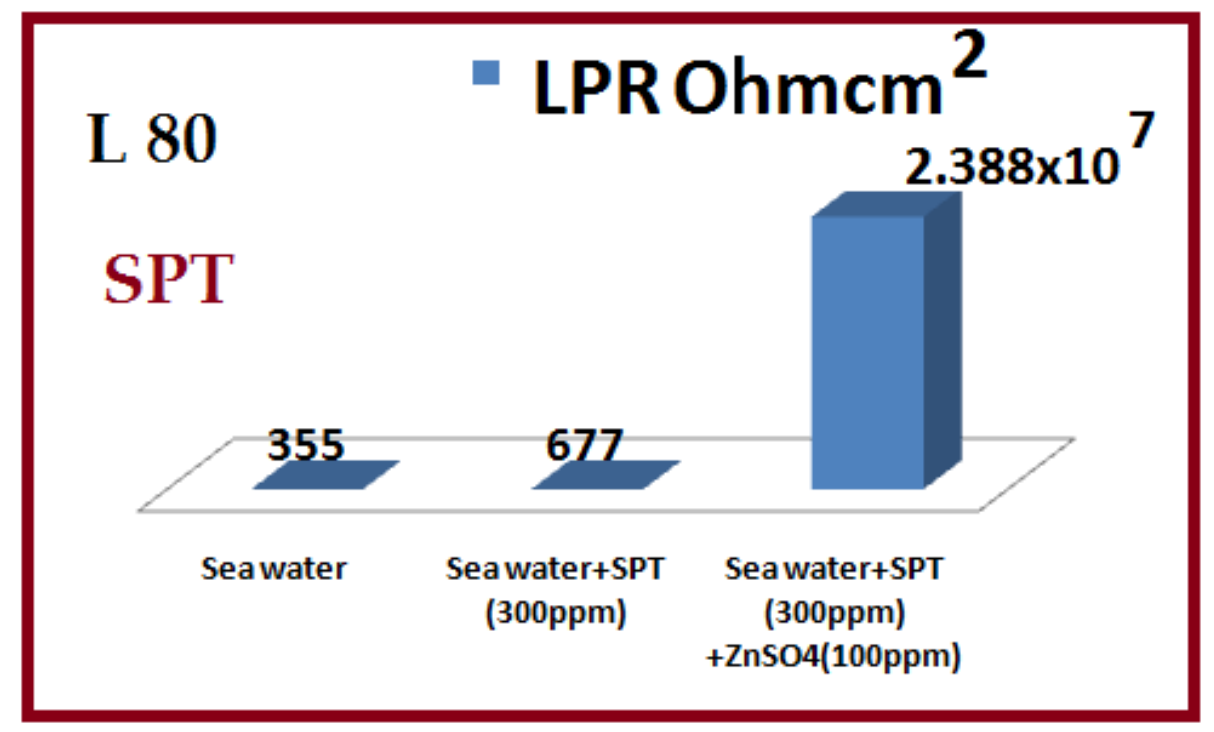

Figure 5. Comparison of $L P R$ values.

\section{AC impedance spectra}

The AC impedance spectra (Nyquist plots, Bode plots) of L80 alloy immersed in various test solutions are shown in Figures 6-11. The corrosion parameters are given in Table 4. It is observed from Table 4, that when SPT is added to sea water, the corrosion resistance of L80 alloy increases. This is revealed by the fact that there is increase in $R_{\mathrm{t}}$ value, impedance value and decrease in $C_{\mathrm{dl}}$ value.

Table 4. Corrosion parameters of L80 alloy immersed in sea water in the absence and presence of SPT and Zinc sulphate $\left(\mathrm{ZnSO}_{4} \cdot 7 \mathrm{H}_{2} \mathrm{O}\right)$ obtained by $\mathrm{AC}$ impedance spectra.

\begin{tabular}{ccccc}
\hline System & $\begin{array}{c}\boldsymbol{R}_{\mathbf{t}} \\
\mathbf{O h m} \cdot \mathbf{c m}^{\mathbf{2}}\end{array}$ & $\begin{array}{c}\boldsymbol{C}_{\mathbf{d l}} \\
\mathbf{F} / \mathbf{c m}^{\mathbf{2}}\end{array}$ & $\begin{array}{c}\text { Impedance } \\
\mathbf{L o g}(\mathbf{z} / \mathbf{O h m})\end{array}$ & $\begin{array}{c}\text { Phase angle } \\
(\mathbf{d e g r e e})\end{array}$ \\
\hline Sea water & 5.026 & $0.010 \times 10^{-4}$ & 0.9149 & 22.03 \\
Sea water + SPT (300 ppm) & 5.653 & $9.021 \times 10^{-7}$ & 0.9604 & 24.01 \\
$\begin{array}{c}\text { Sea water + SPT (300 ppm) }+ \\
\text { ZnSO } 4 \text { (100 ppm) }\end{array}$ & $1.281 \cdot 10^{7}$ & $3.982 \cdot 10^{-13}$ & 7.123 & 96.33 \\
\hline
\end{tabular}




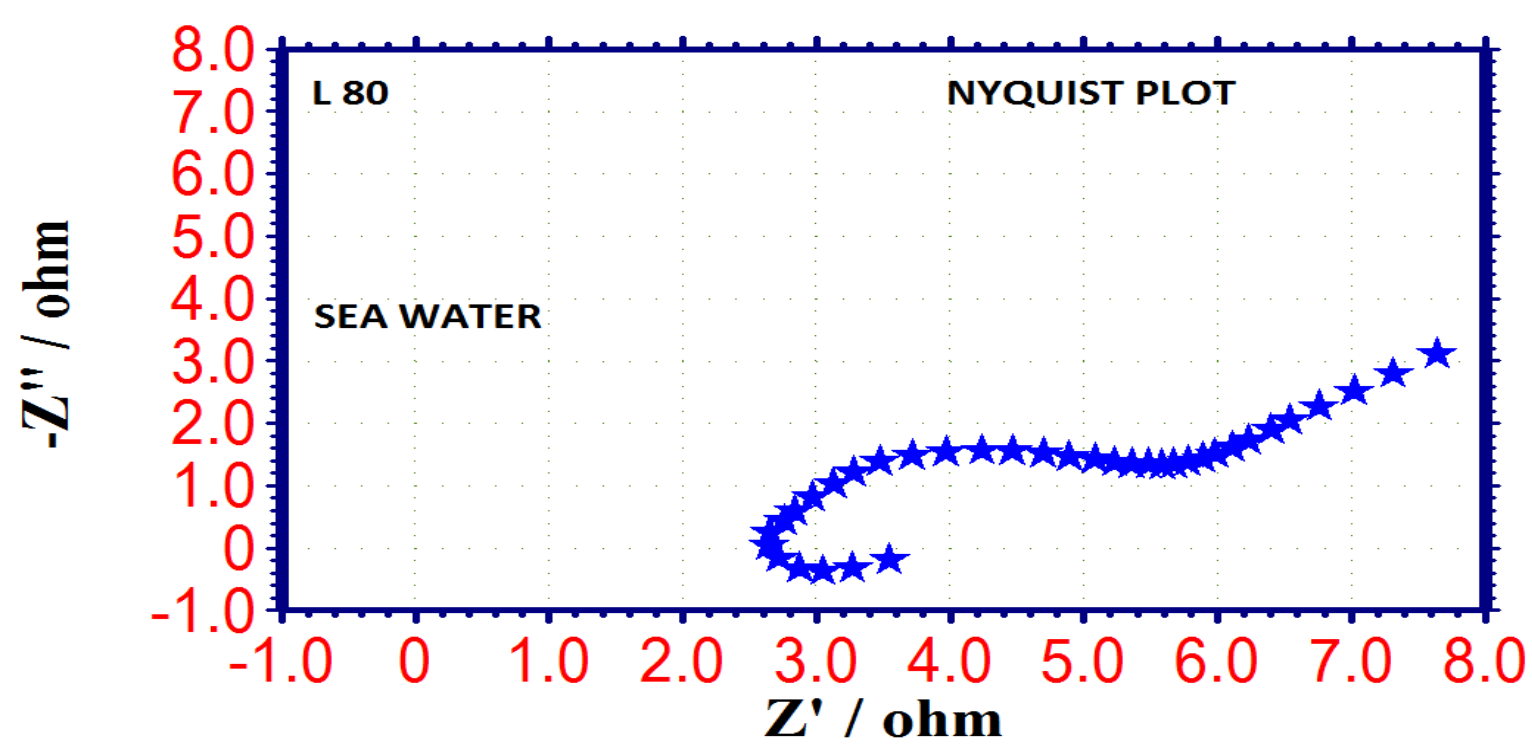

Figure 6. AC impedance spectra (Nyquist plot) of L80 alloy immersed in sea water.
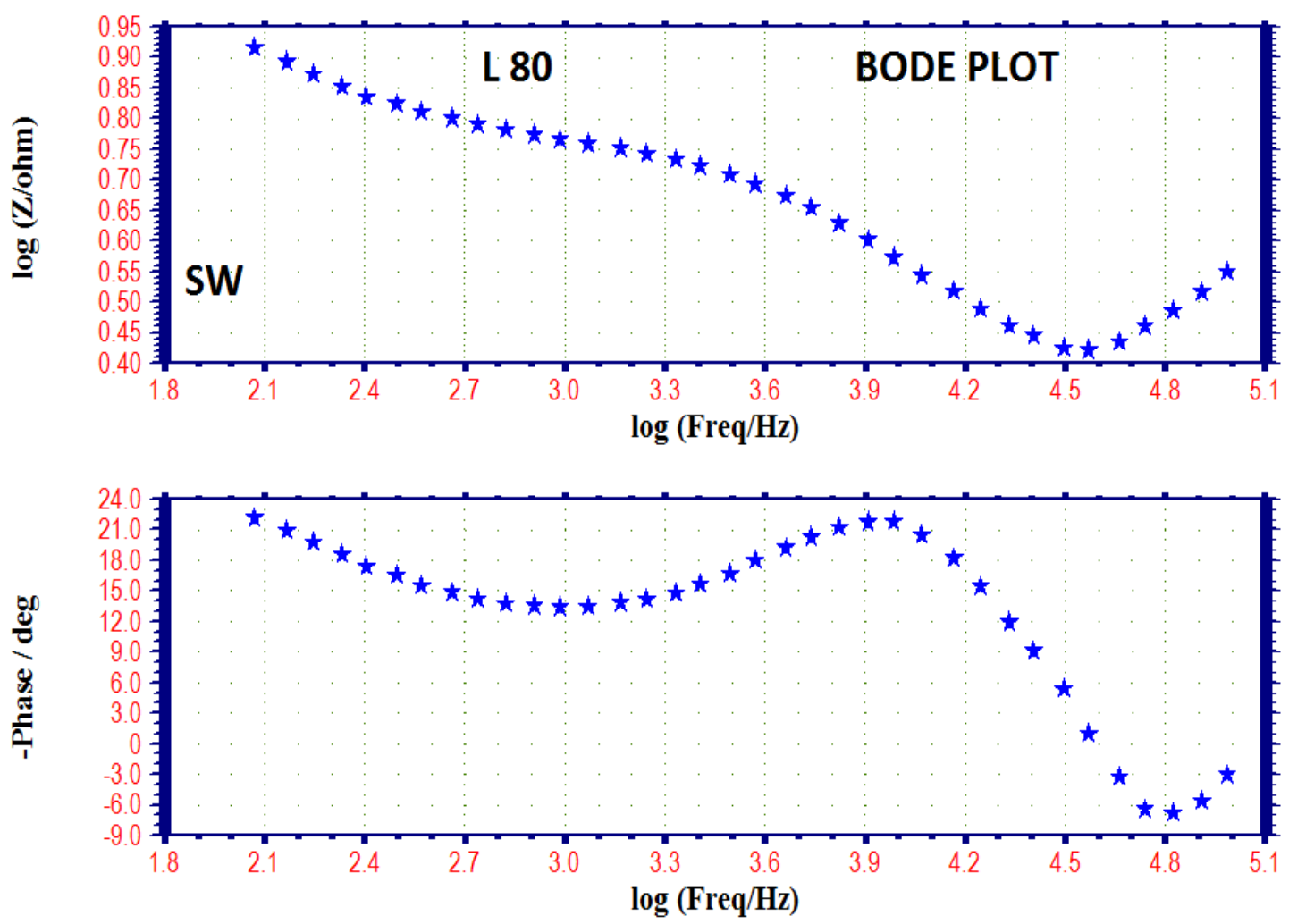

Figure 7. AC impedance spectra (Bode plot) of L80 alloy immersed in sea water. 


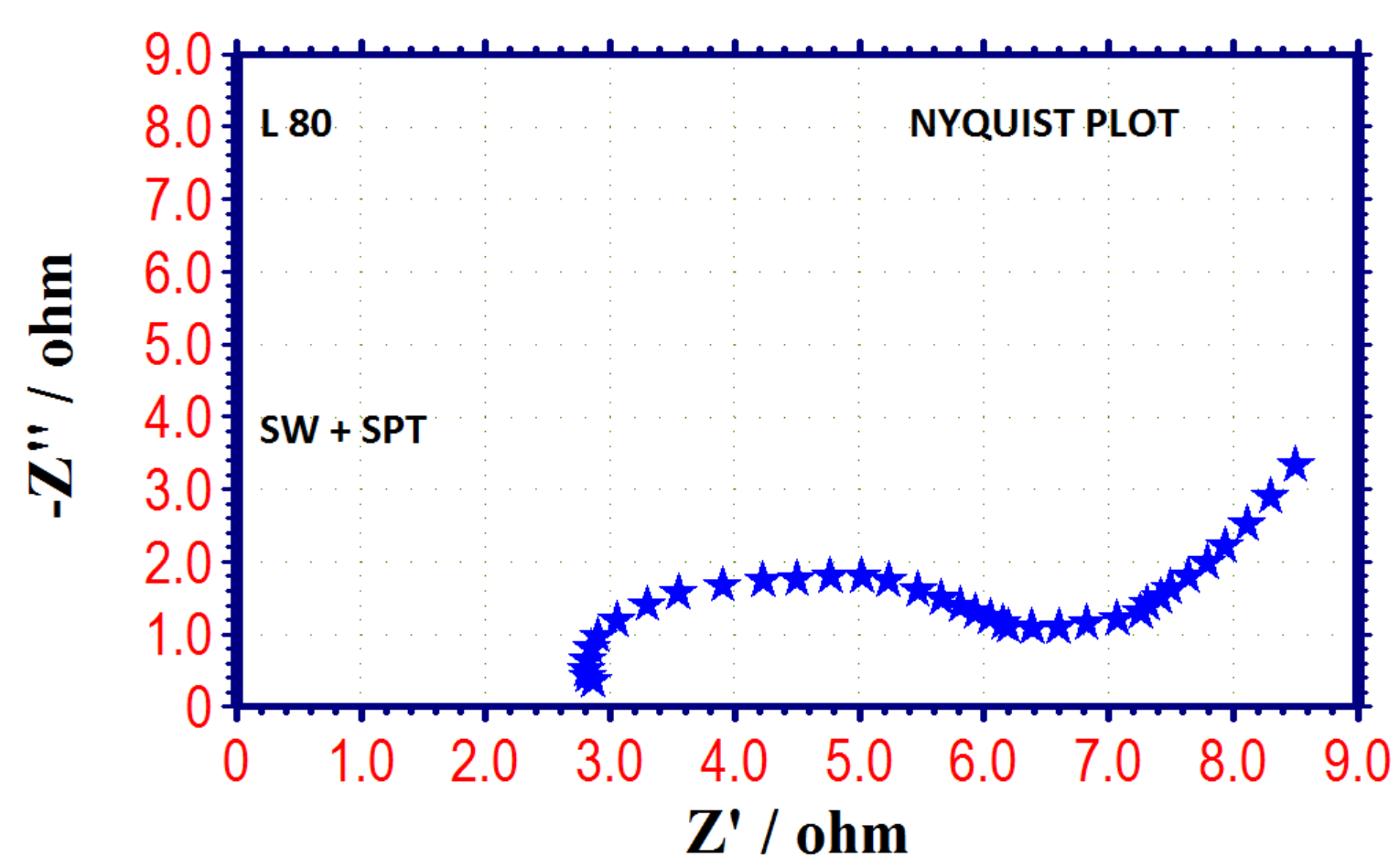

Figure 8. AC impedance spectra (Nyquist plot) of L80 alloy immersed in sea water + SPT.
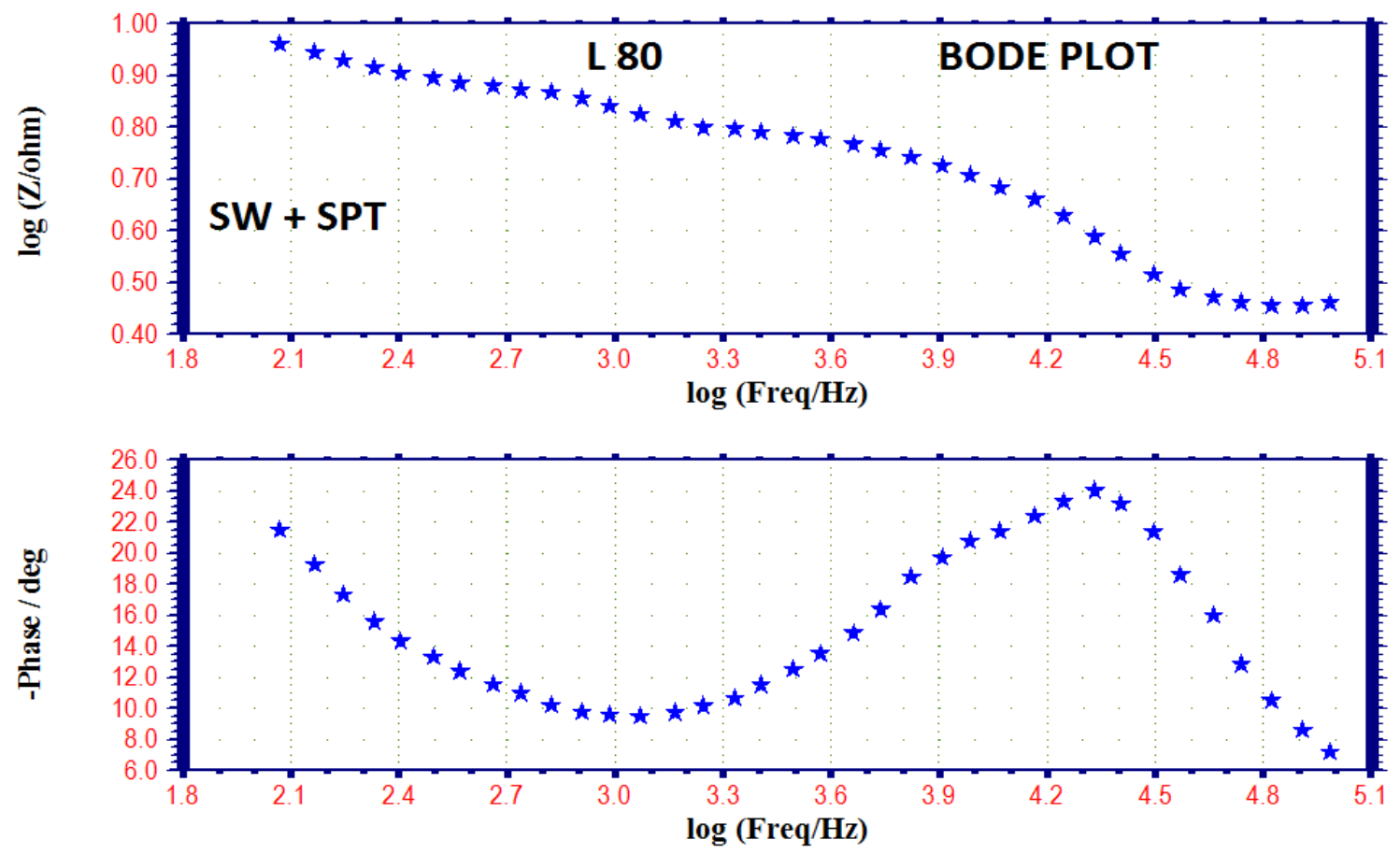

Figure 9. AC impedance spectra (Bode plot) of L80 alloy immersed in sea water + SPT. 


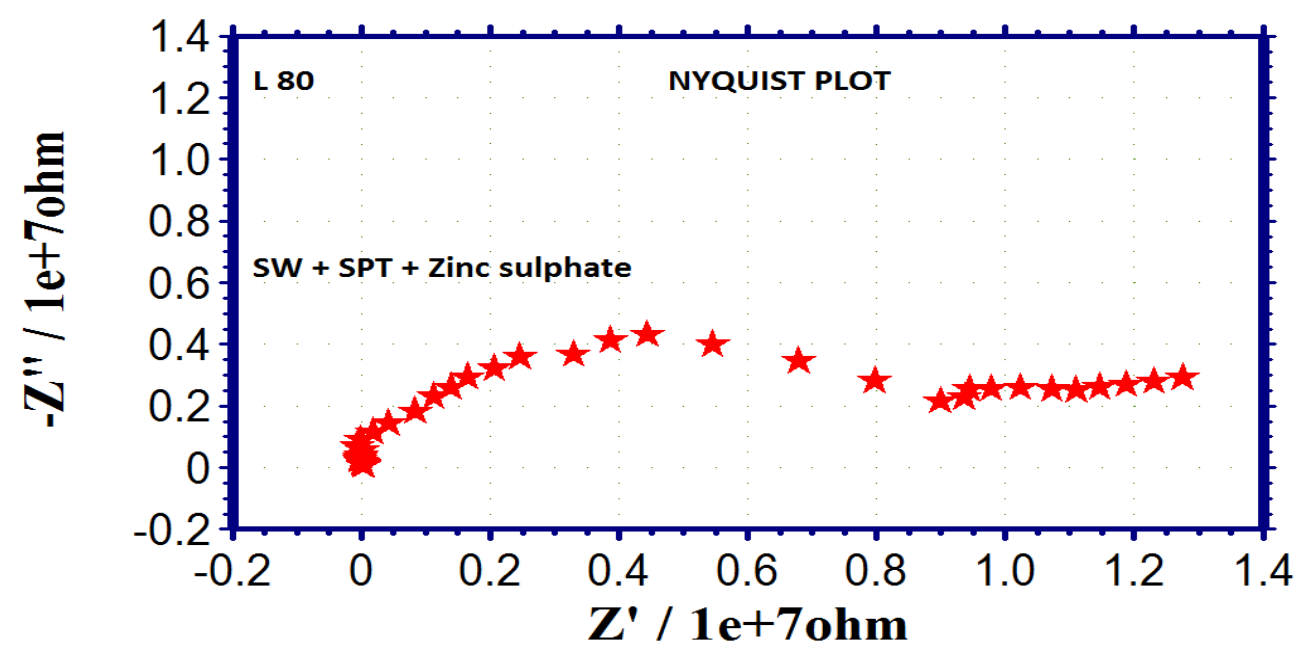

Figure 10. AC impedance spectra (Nyquist plot) of L80 alloy immersed in sea water + SPT + zinc sulphate.
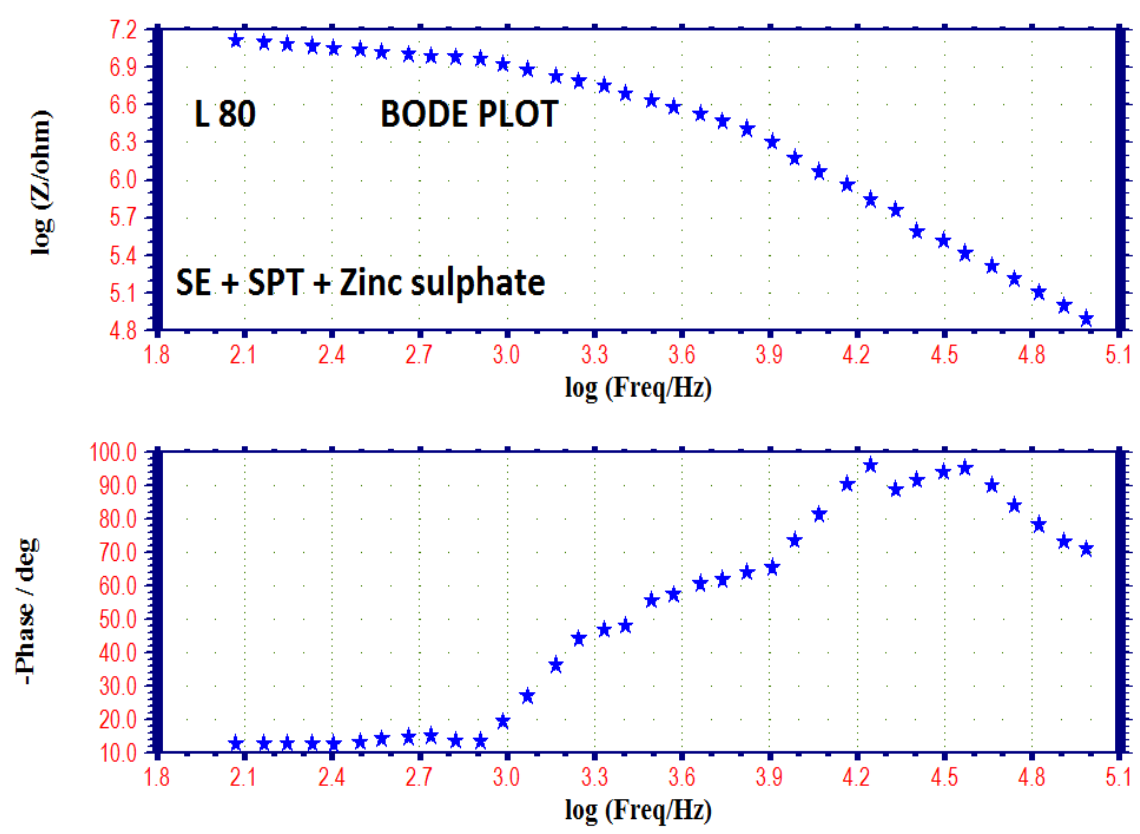

Figure 11. AC impedance spectra (Bode plot) of mild steel immersed in sea water + SPT + $\mathrm{ZnSO}_{4}$.

Influence of zinc sulphate $\left(\mathrm{ZnSO}_{4} \cdot 7 \mathrm{H}_{2} \mathrm{O}\right)$

When $\mathrm{ZnSO}_{4} \cdot 7 \mathrm{H}_{2} \mathrm{O}$ is added to the above SPT system, the corrosion resistance further increases (Figure 12). This is revealed by the fact that there is increase in $R_{\mathrm{t}}$ value and impedance value. There is decrease in $C_{\mathrm{dl}}$ value. The tremendous increase in $R_{\mathrm{t}}$ value is due to the synergistic effect existing between TSC and $\mathrm{Zn}^{2+}$. Thus electrochemical studies reveal that the corrosion resistance of L80 alloy in sea water decreases in the following order: 


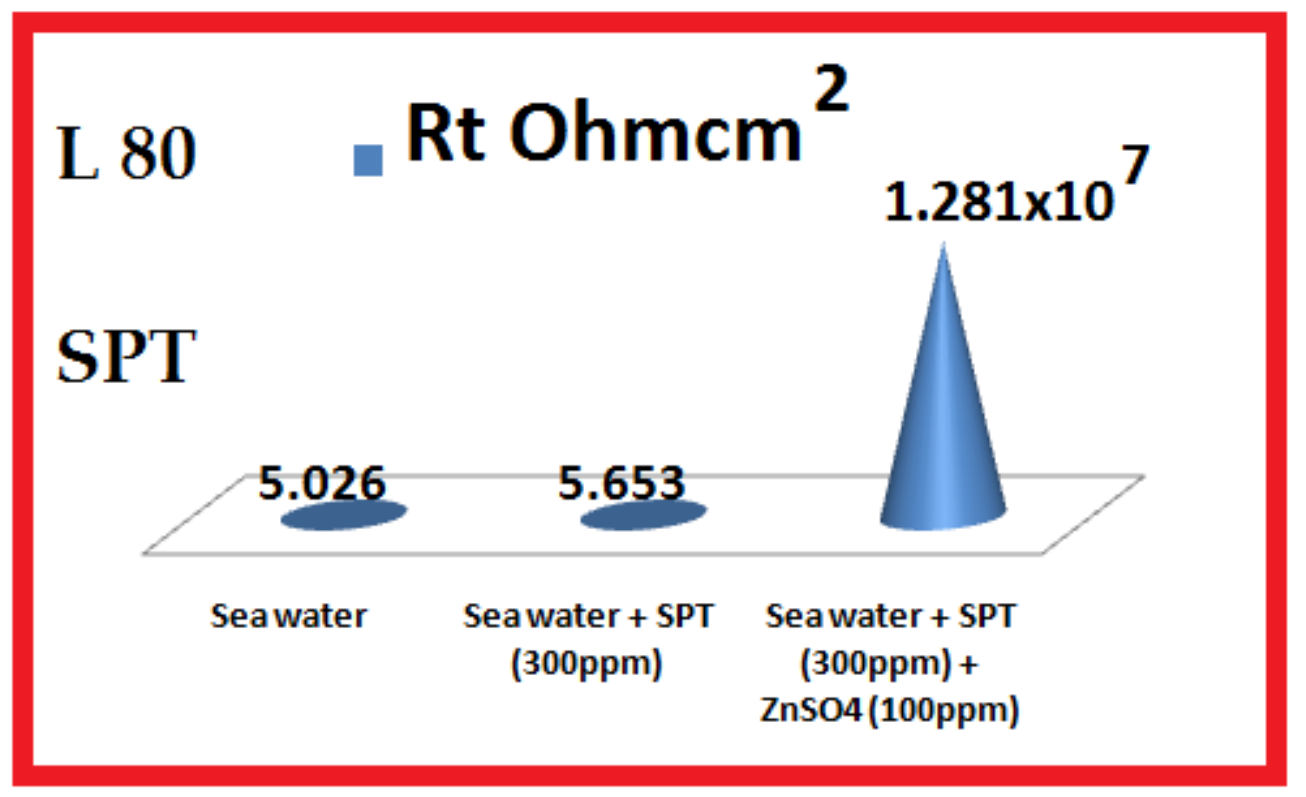

Figure 12. Comparison of $R_{\mathrm{t}}$ values.

L80 Alloy-TSC system

\section{Polarization study}

The polarization parameters of L80 alloy immersed in sea water in presence of TSC system are given in Table 5. The polarization curves are shown in Figures 13 and 14. It is seen from Table 5 that when TSC is added to sea water, the corrosion resistance of L80 alloy increases. This is revealed by the fact that when TSC is added to sea water, the $L P R$ value increases and $I_{\text {corr }}$ value decreases (Figures 13,14). There is formation of a protective film on the metal surface. So transfer of electron from anodic site to cathodic site is restricted. Hence $L P R$ value increases and correspondingly corrosion current value decreases.

Table 5. Corrosion parameters of L80 alloy immersed in sea water in the absence and presence of TSC and zinc sulphate $\left(\mathrm{ZnSO}_{4} \cdot 7 \mathrm{H}_{2} \mathrm{O}\right)$ obtained by polarization study.

\begin{tabular}{cccccc}
\hline System & $\begin{array}{c}\boldsymbol{E}_{\text {corr }} \\
\mathbf{m V ~ S C E}\end{array}$ & $\begin{array}{c}\boldsymbol{b}_{\mathbf{c}} \\
\mathbf{m V} / \mathbf{d e c a d e}\end{array}$ & $\begin{array}{c}\boldsymbol{b}_{\mathbf{a}} \\
\mathbf{m V} / \mathbf{d e c a d e}\end{array}$ & $\begin{array}{c}\mathbf{L P R} \\
\mathbf{O h m} \cdot \mathbf{c m}^{2}\end{array}$ & $\begin{array}{c}\boldsymbol{I}_{\text {corr }} \\
\mathbf{A} / \mathbf{c m}^{2}\end{array}$ \\
\hline Sea water & -830 & 161 & 221 & 355 & $1.138 \cdot 10^{-4}$ \\
Sea water +TSC (300 ppm) & -761 & 165 & 232 & 391 & $1.076 \cdot 10^{-4}$ \\
$\begin{array}{c}\text { Sea water +TSC (300 ppm) }+ \\
\text { ZnSO (100 ppm) }\end{array}$ & -704 & 146 & 209 & 465 & $8.044 \cdot 10^{-5}$ \\
\hline
\end{tabular}




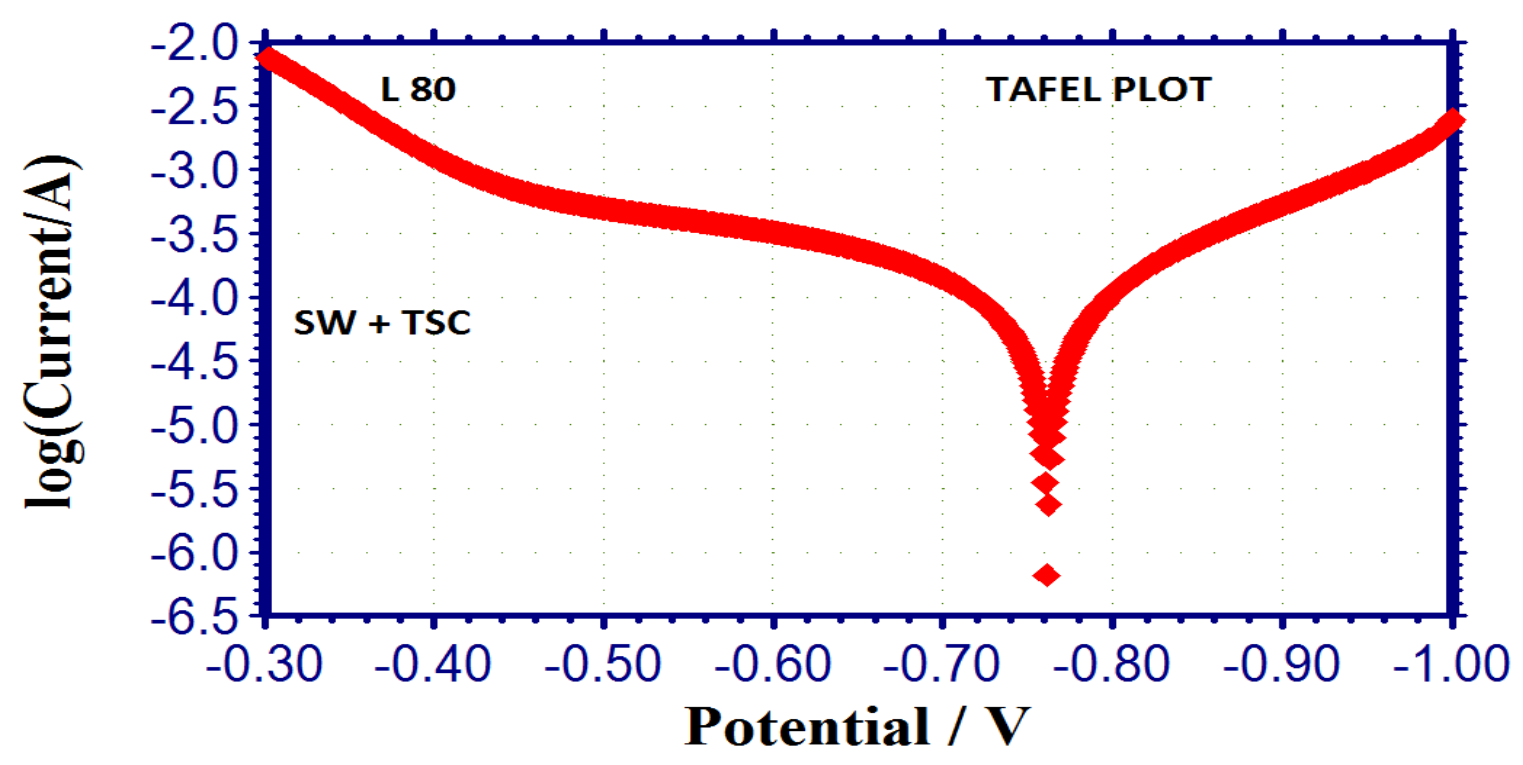

Figure 13. Polarisation curve of L80 alloy immersed in sea water + TSC.

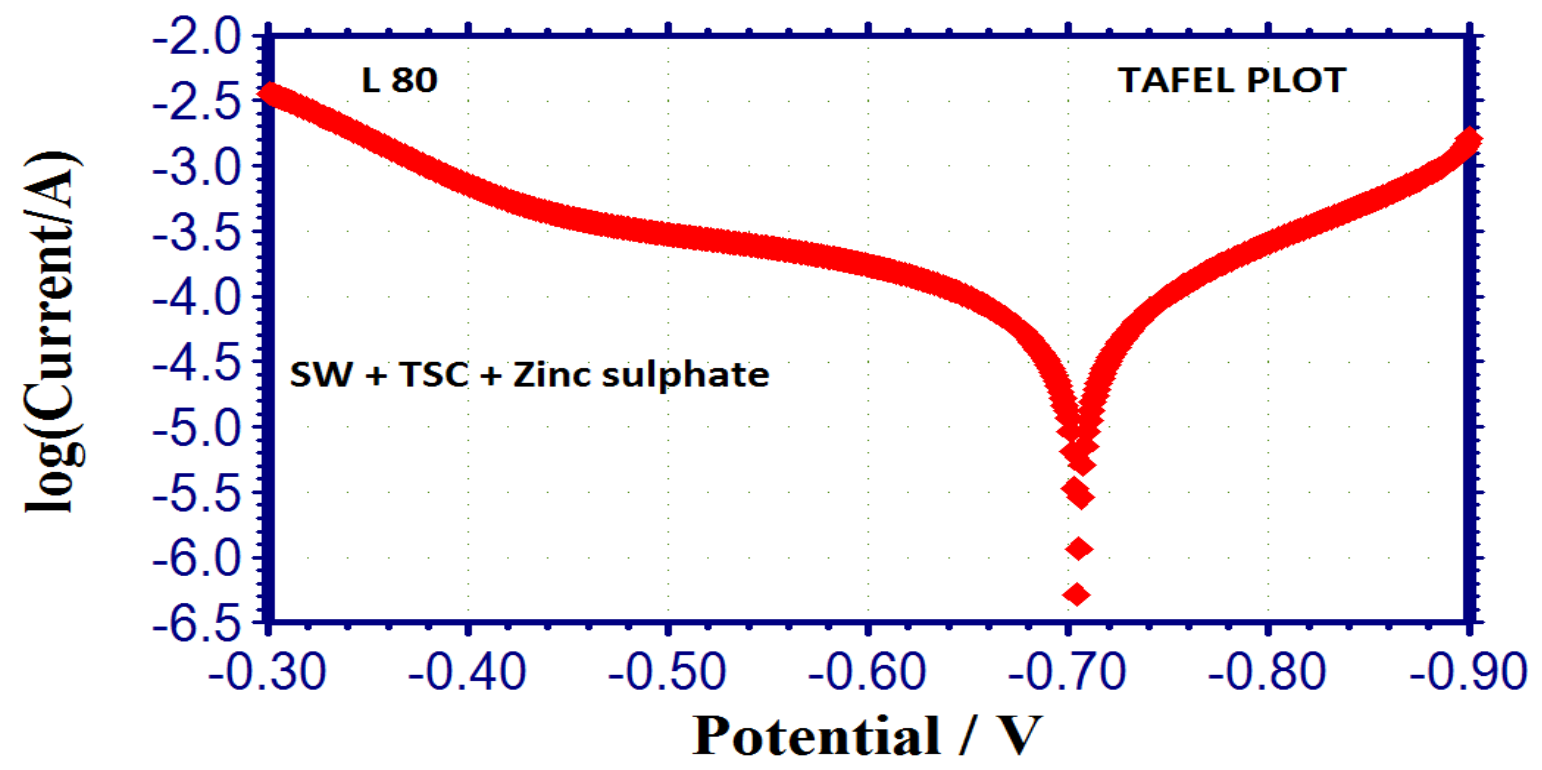

Figure 14. Polarisation curve of L80 alloy immersed in sea water + TSC + zinc sulphate.

Influence of zinc sulphate $\left(\mathrm{ZnSO}_{4} \cdot 7 \mathrm{H}_{2} \mathrm{O}\right)$

When $\mathrm{ZnSO}_{4} \cdot 7 \mathrm{H}_{2} \mathrm{O}$ is added to the above system, the $L P R$ value increases tremendously to a very great extent (Figure 15) and the $I_{\text {corr }}$ decreases very much. This indicates that in presence of SPT $-\mathrm{ZnSO}_{4} \cdot 7 \mathrm{H}_{2} \mathrm{O}$ system the corrosion resistance of $\mathrm{L} 80$ alloy in sea water increases to a great extent. This is due to the synergistic effect existing between SPT and $\mathrm{Zn}^{2+}$. 


\section{L80 \\ - LPR Ohmcm ${ }^{2}$}

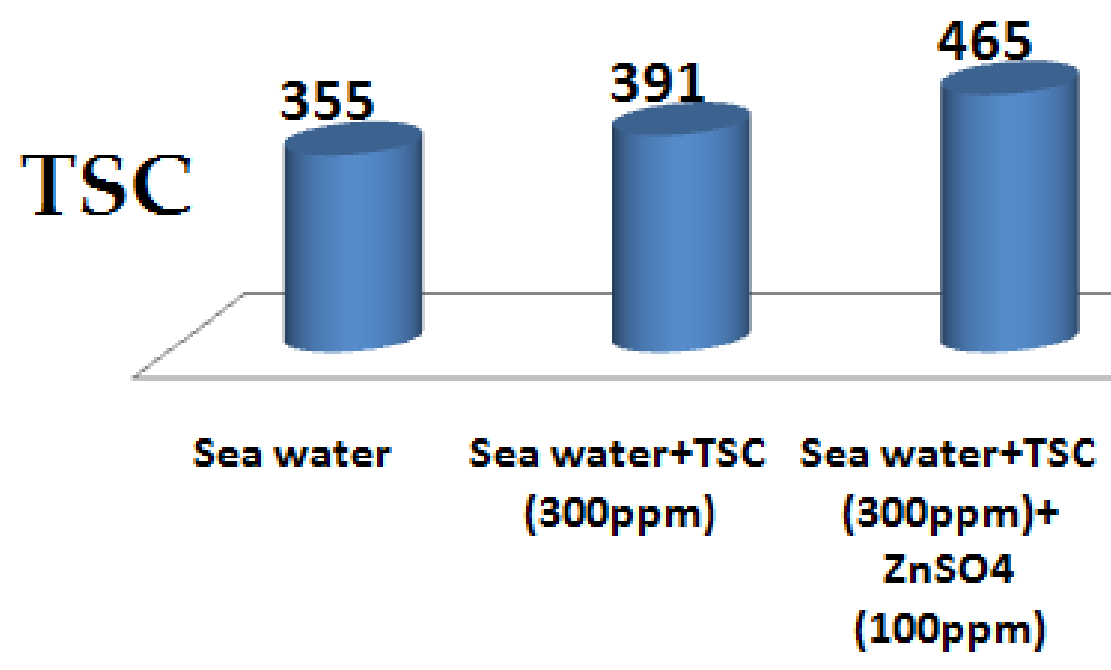

Figure 15. Comparison $L P R$ values.

\section{AC impedance spectra}

The AC impedance spectra (Nyquist plots, Bode plots) of L80 alloy immersed in various test solutions are shown in Figures 16-19. The corrosion parameters are given in Table 6. It is observed from Table 6 that when TSC is added to sea water, the corrosion resistance of L80 alloy increases. This is revealed by the fact that there is increase in $R_{\mathrm{t}}$ value, impedance value and decrease in $C_{\mathrm{dl}}$ value.

Table 6. Corrosion parameters of L80 alloy immersed in sea water in the absence and presence of TSC and Zinc sulphate $\left(\mathrm{ZnSO}_{4} \cdot 7 \mathrm{H}_{2} \mathrm{O}\right)$ obtained by $\mathrm{AC}$ impedance spectra.

\begin{tabular}{ccccc}
\hline System & $\begin{array}{c}\boldsymbol{R} \mathbf{t} \\
\mathbf{O h m} \cdot \mathbf{c m}^{2}\end{array}$ & $\begin{array}{c}\boldsymbol{C}_{\mathbf{d l}} \\
\mathbf{F} / \mathbf{c m}^{2}\end{array}$ & $\begin{array}{c}\text { Impedance } \\
\mathbf{L o g}(\mathbf{z} / \mathbf{O h m})\end{array}$ & $\begin{array}{c}\text { Phase angle } \\
\text { degree }\end{array}$ \\
\hline Sea water & 5.026 & $0.010 \cdot 10^{-4}$ & 0.9149 & 22.03 \\
Sea water + TSC (300 ppm) & 6.282 & $0.022 \cdot 10^{-4}$ & 0.9671 & 26.22 \\
$\begin{array}{c}\text { Sea water + TSC (300 ppm) }+ \\
\text { ZnSO }(100 \mathrm{ppm})\end{array}$ & 7.077 & $7.206 \cdot 10^{-7}$ & 1.021 & 28.84 \\
\hline
\end{tabular}




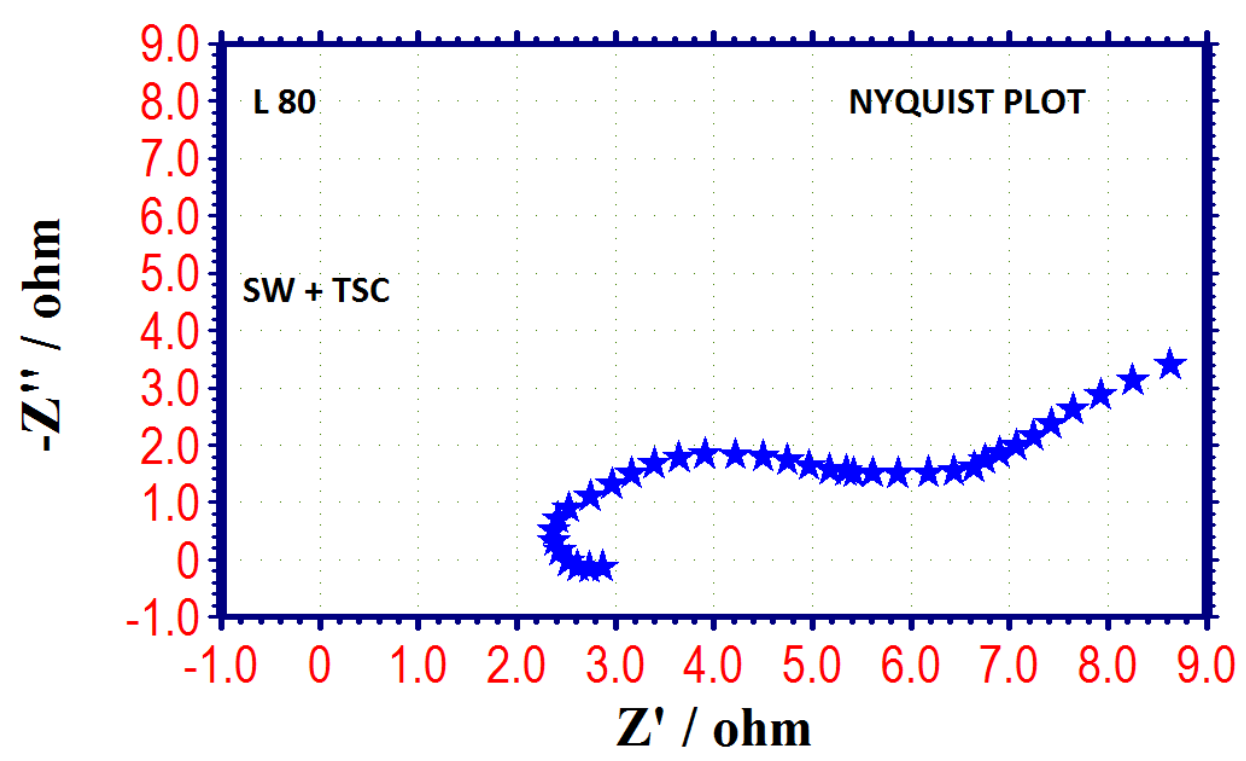

Figure 16. AC Impedance spectra (Nyquist plot) of L80 alloy immersed in sea water + TSC.
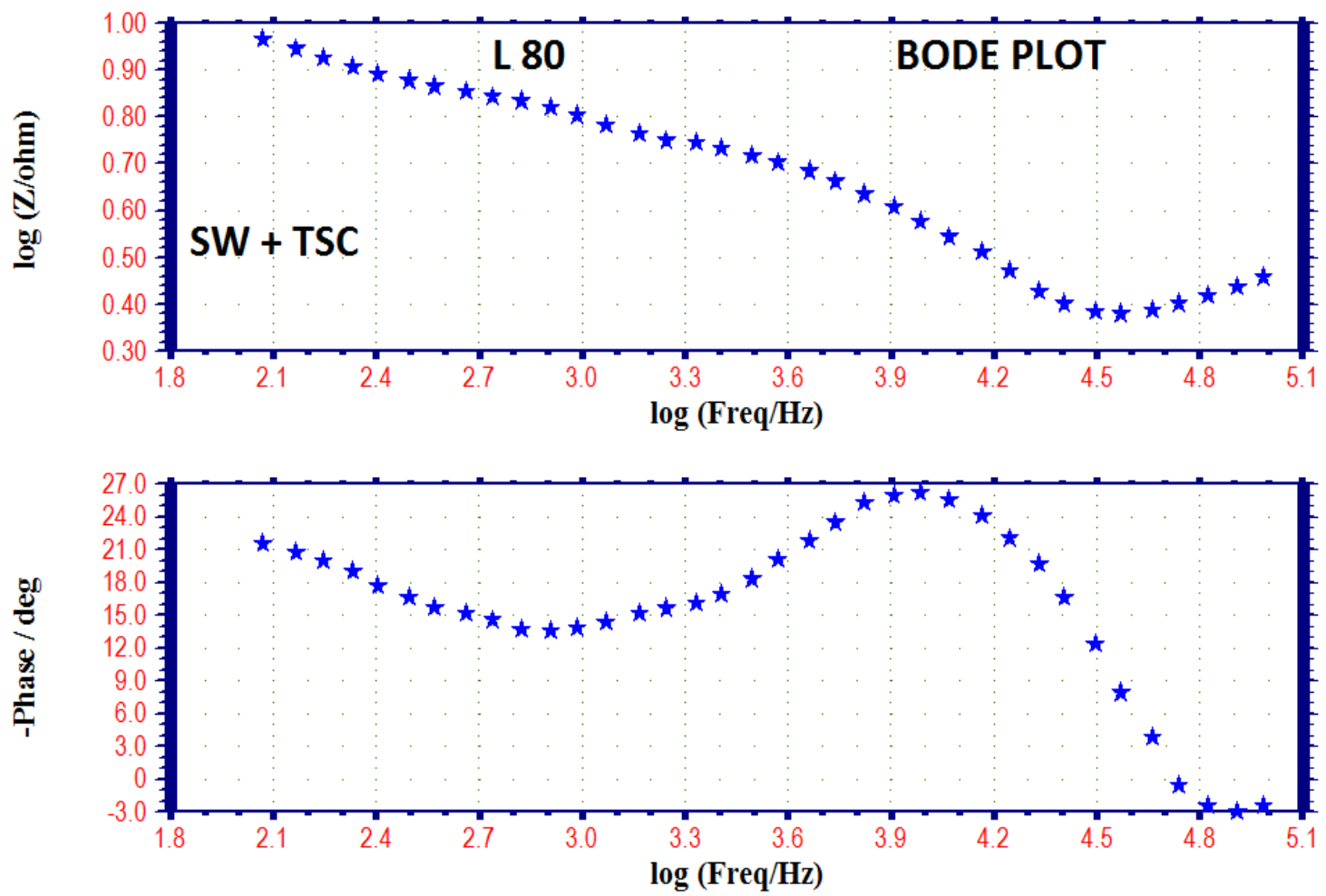

Figure 17. AC impedance spectra (Bode plot) of L80 alloy immersed in sea water + TSC. 


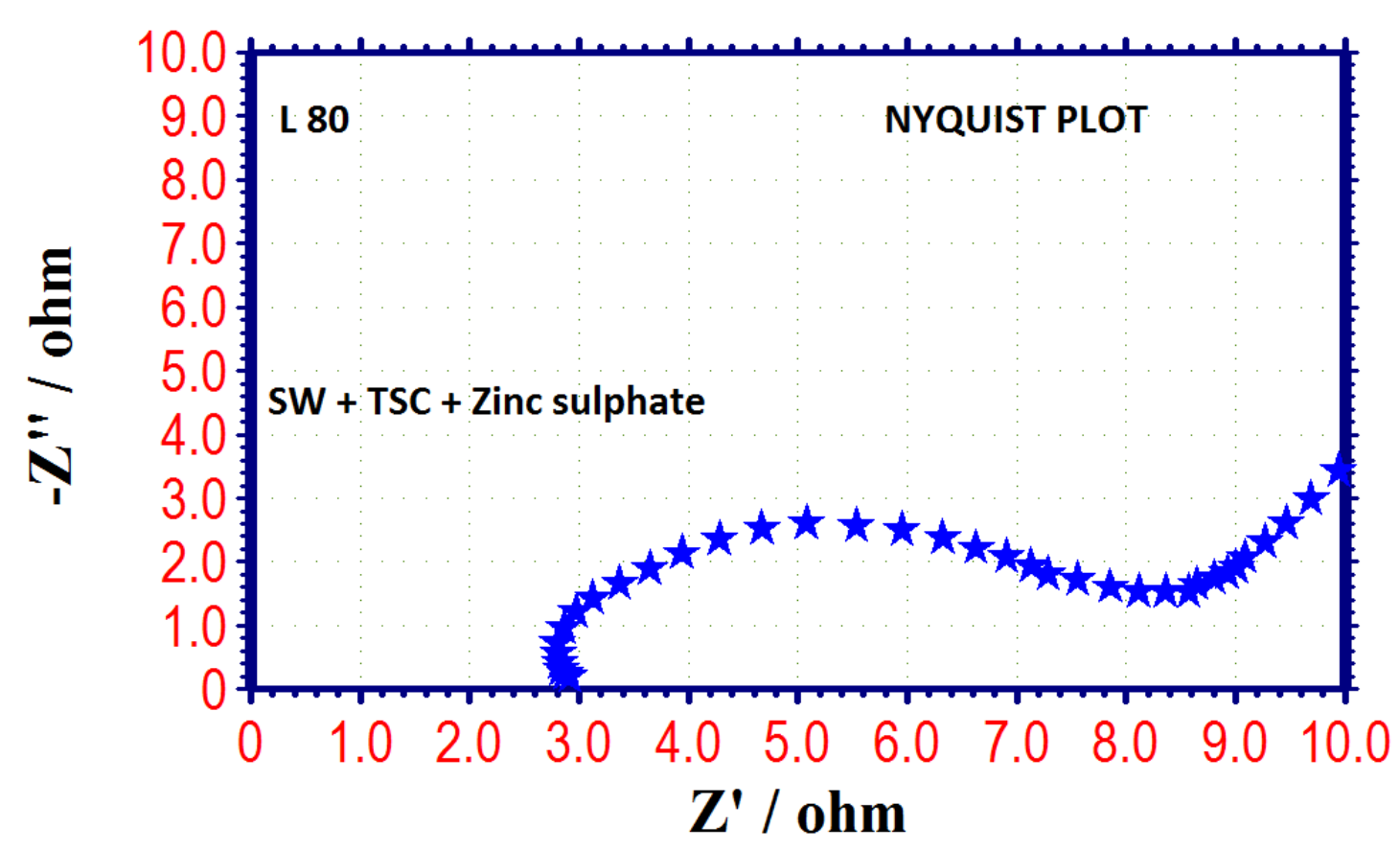

Figure 18. AC impedance spectra (Nyquist plot) of L80 alloy immersed in sea water + TSC + $\mathrm{ZnSO}_{4}$.
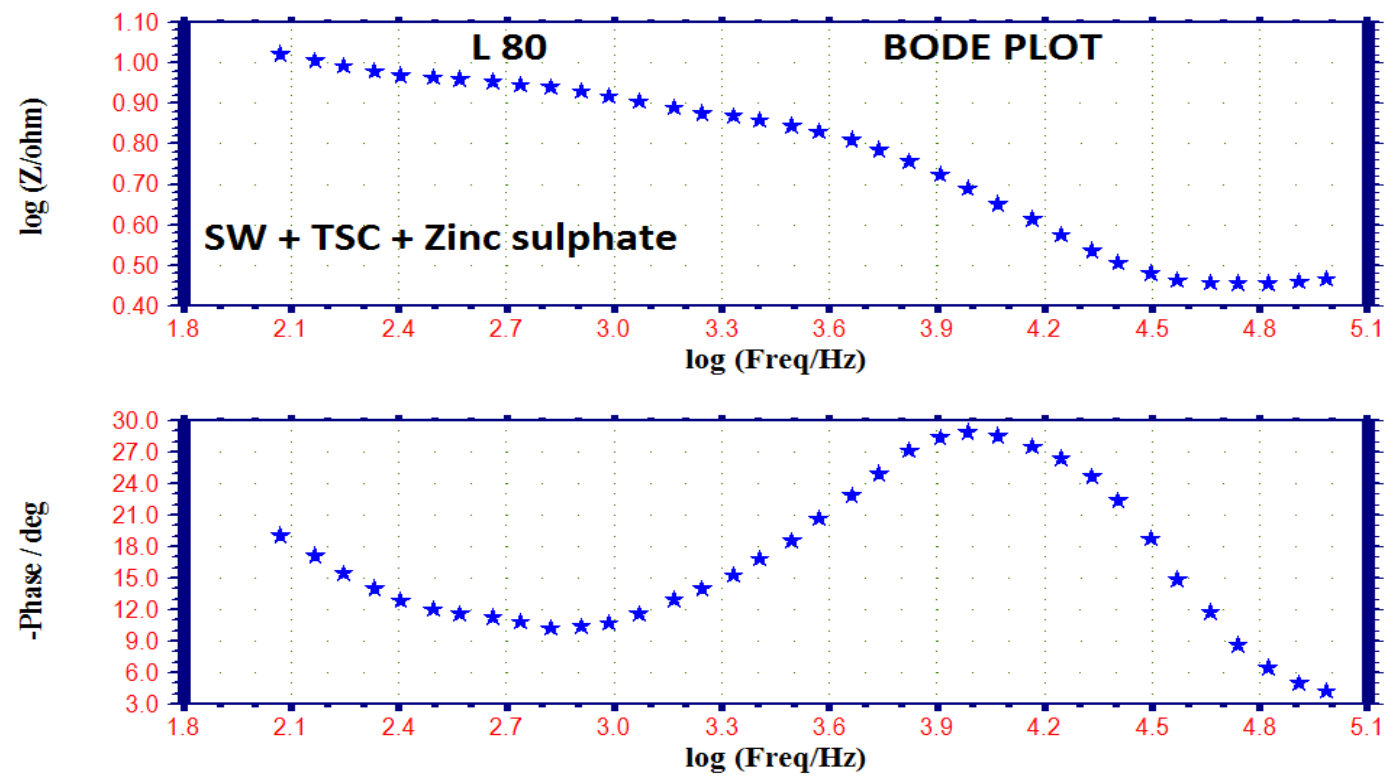

Figure 19. AC impedance spectra (Bode plot) of L80 alloy immersed in sea water + TSC + $\mathrm{ZnSO}_{4}$.

Influence of zinc sulphate $\left(\mathrm{ZnSO}_{4} \cdot 7 \mathrm{H}_{2} \mathrm{O}\right)$

When $\mathrm{ZnSO}_{4} \cdot 7 \mathrm{H}_{2} \mathrm{O}$ is added to the above TSC system, the corrosion resistance further increases. This revealed by the fact that there is increase in $R_{\mathrm{t}}$ values (Figure 20) and impedance value. There is decrease in $C_{\mathrm{dl}}$. Thus electrochemical studies such as polarisation 
study and AC impedance spectra [19-36] reveal that the corrosion resistance of L80 alloy in sea water decreases in the following order:

Sea water $+\mathrm{TSC}+\mathrm{ZnSO}_{4}>$ Sea water $+\mathrm{TSC}>$ Sea water

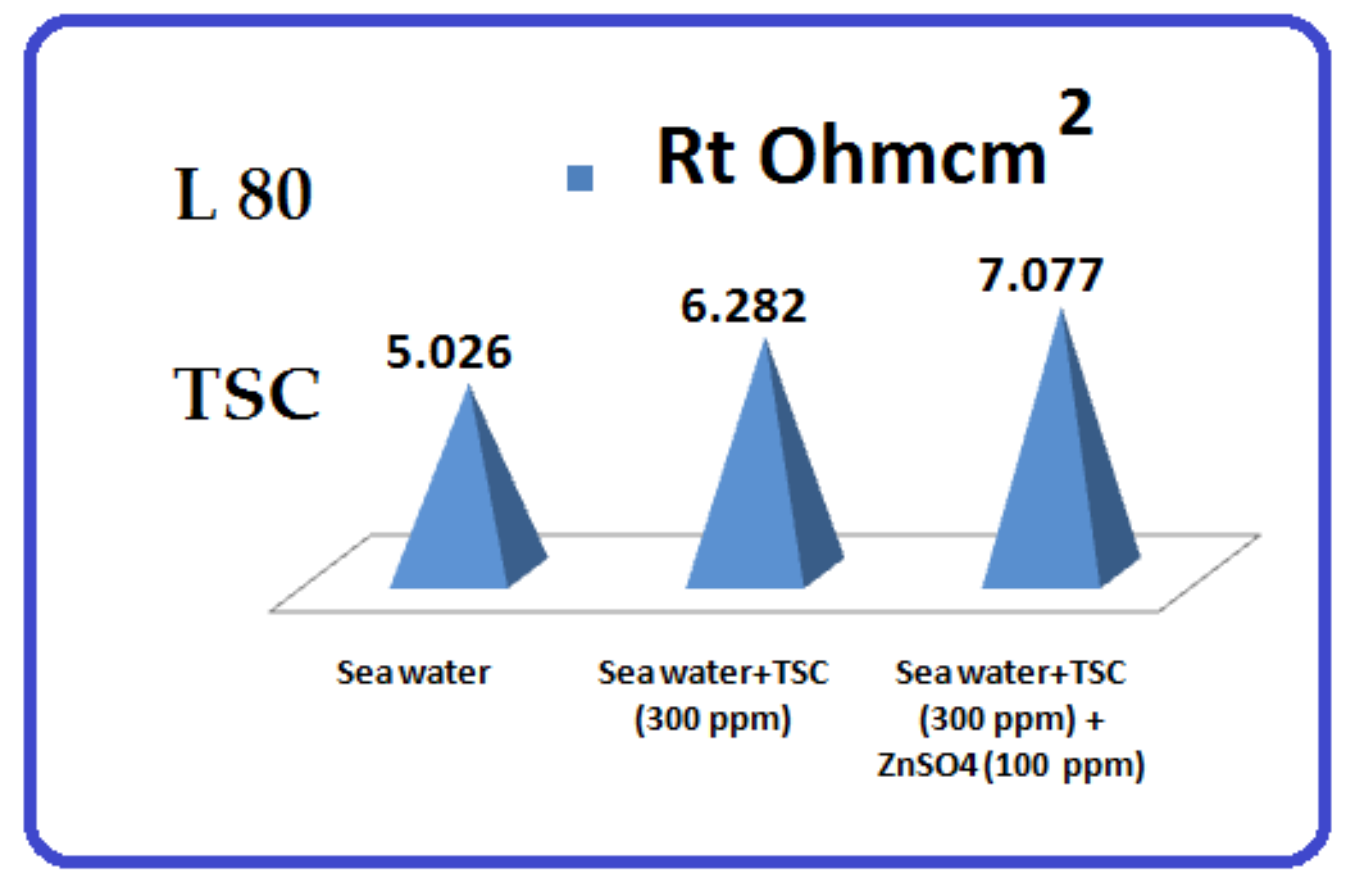

Figure 20. Comparison of $R_{\mathrm{t}}$ values.

Equivalent circuit diagram for the Nyquist plots

The Nyquist plots (Figures 6, 8,10,16 and 18) in the present study reveal that diffusion controlled reactions are involved in the corrosion controlling processes. The equivalent circuit diagram is shown is Figure 21.

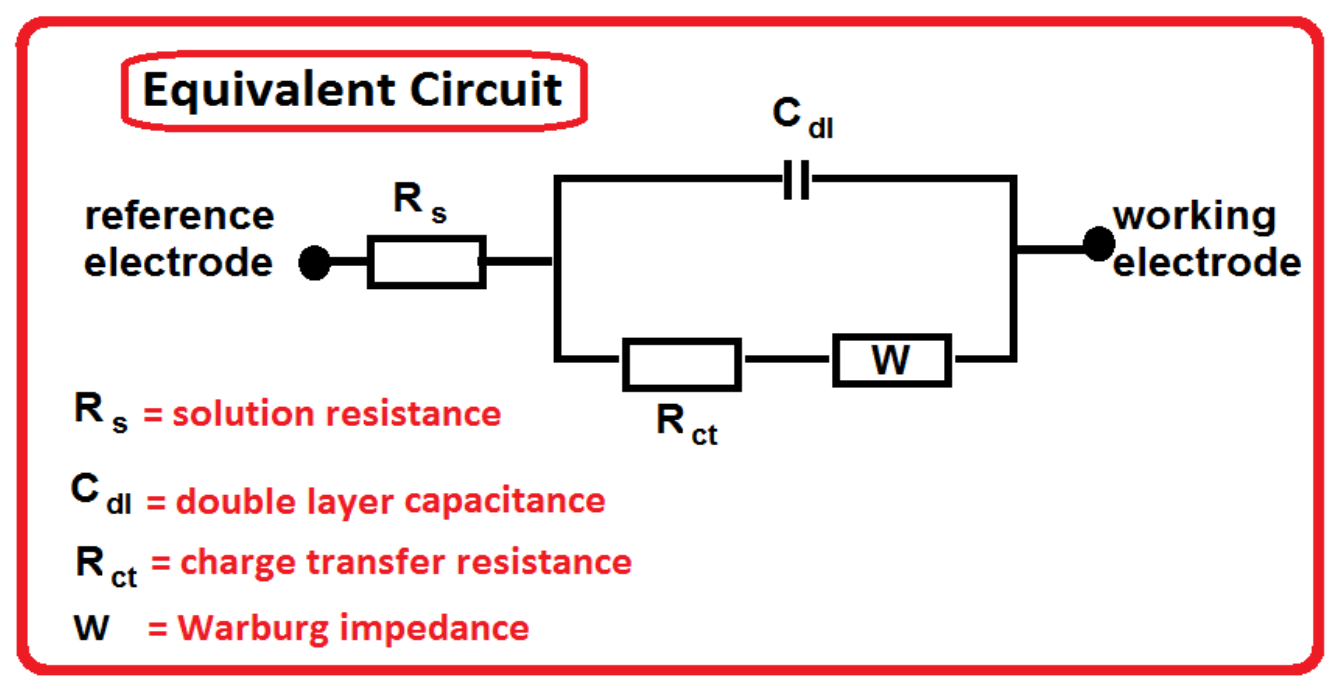

Figure 21. Equivalent circuit diagram for diffusion controlled process. 


\section{Mechanism of corrosion inhibition}

In presence of $\mathrm{Zn}^{2+}$, corrosion resistance of the metal further increases (better than the SPT/TSC system alone), which is supported by the fact that the linear polarisation resistance value further increases and corrosion current value further decreases. Similarly during electrochemical impedance study, charge transfer value increases tremendously and double layer capacitance value decreases to a great extent. It is inferred that in presence of $\mathrm{Zn}^{2+}$, more inhibitor (SPT/TSC) is transported towards the metal surface, as $\mathrm{Zn}^{2+}$-inhibitor complex. On the metal surface iron inhibitor complex is formed on the anodic sites of the metal surface and $\mathrm{Zn}^{2+}$ is released. The released $\mathrm{Zn}^{2+}$ combines with $\mathrm{OH}^{-}$to form $\mathrm{Zn}(\mathrm{OH})_{2}$ complex on the cathodic sites of the metal surface. Thus in presence of $\mathrm{Zn}^{2+}$, both anodic reaction and cathodic reaction are controlled effectively. This accounts for the increase in corrosion resistance of metal in sea water in presence of inhibitor and $\mathrm{Zn}^{2+}$. In presence of $\mathrm{Zn}^{2+}$ and inhibitor a loose complex is formed between $\mathrm{Zn}^{2+}$ and inhibitor. The bond between them is strong enough to carry the inhibitor to the metal surface and weak enough to release the inhibitor in presence of $\mathrm{Fe}^{2+}$ to form $\mathrm{Fe}^{2+}$-inhibitor complex on the anodic sites of the metal surface (Figures 22 and 23).

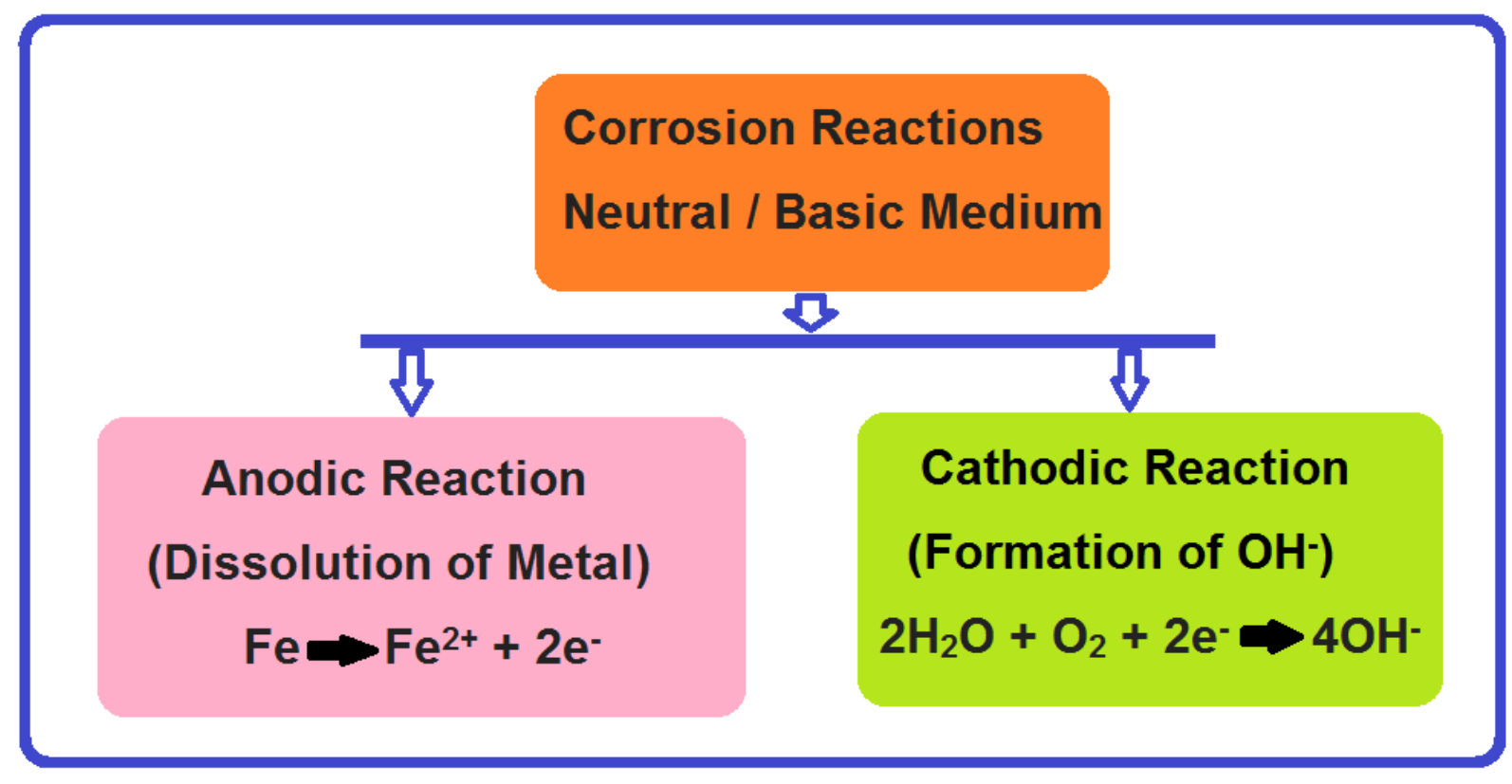

Figure 22. Anodic and cathodic reactions in corrosion process. 


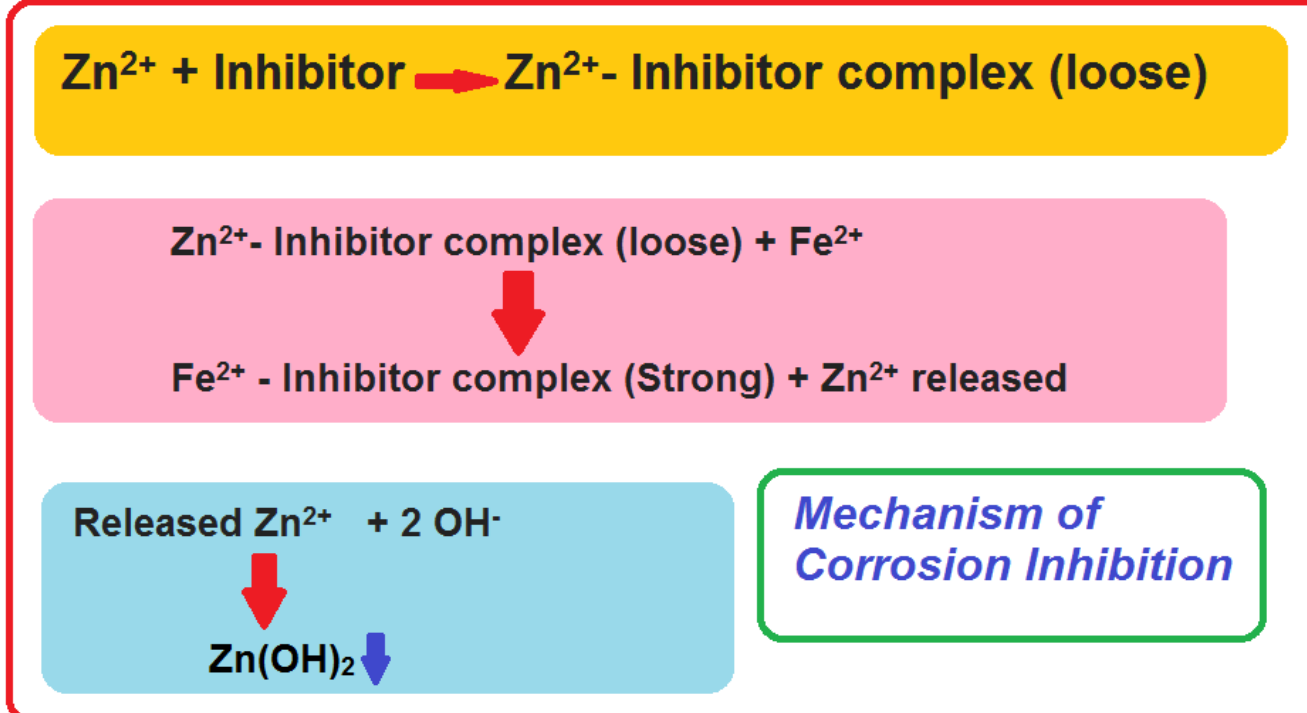

Figure 23. Corrosion inhibition mechanism.

\section{Conclusion}

The corrosion resistance of L80 alloy in sea water in the absence and presence of sodium potassium tartrate (SPT), trisodium citrate (TSC) and zinc sulphate $\left(\mathrm{ZnSO}_{4} \cdot 7 \mathrm{H}_{2} \mathrm{O}\right)$ has been evaluated by electrochemical studies such as polarization study and $\mathrm{AC}$ impedance spectra. The study leads to the following conclusions:

L80 alloy - SPT system

Electrochemical studies reveal that the corrosion resistance of L80 alloy in sea water decreases in the following order:

Sea water $+\mathrm{SPT}+\mathrm{ZnSO}_{4}>$ Sea water $+\mathrm{SPT}>$ Sea water

L80 alloy - TSC system

Electrochemical studies reveal that the corrosion resistance of L80 alloy in sea water decreases in the following order:

Sea water $+\mathrm{TSC}+\mathrm{ZnSO}_{4}>$ Sea water $+\mathrm{TSC}>$ Sea water

Addition of zinc sulphate improves the corrosion resistance of the TSC and SPT systems.

\section{Acknowledgment}

The authors are thankful to their respective managements for their help and encouragement. Special thanks to Rev. Dr. Antony Pushpa Ranjitham (Superior General), Rev. Sr. Thanaseeli Sengole (Asst. General), Rev. Sr. M. Margaret Inbaseeli (College Secretary), Rev. 
Dr. Pramila (Principal), Rev. Sr. Gnana Soundari (Provincial) and Mrs J. Antony Justina Mary (Vice Principal) for their Prayer and Blessings.

\section{References}

1. https://www.britannica.com/science/seawater

2. http://www.marinebio.net/marinescience/02ocean/swcomposition.htm

3. M.M. Osman, Corrosion inhibition of aluminium-brass in $3.5 \% \mathrm{NaCl}$ solution and sea water, Mater. Chem. Phys., 2001, 71, 12-16. doi: 10.1016/S0254-0584(00)00510-1

4. L.J. Berchmans, S.V. Iyer, V. Sivan and M.A. Quaraishi, 1,2,4,5 tetrazo spiro $(5,4)$ decane-3 thione as a corrosion inhibitor for arsenical aluminium brass in $3.5 \% \mathrm{NaCl}$ solution, Anti-Corros. Methods Mater., 2001, 48, 376-381. doi: 10.1108/EUM0000000006259

5. Cui Wang, Bin Xiang, Cui Wang, Jie Zhang, Ji-Zhou Duan, Bao-Rong Hou and XiaoLin Chen, Inhibition of Zinc Corrosion by Fucoidan in Natural Sea water, Acta Metall. Sin. (Engl. Lett. , 2017, 30, 594-600. https://doi.org/10.1007/s40195-016-0524-9

6. K.K. Taha and A. Muhideen, Characterization of anti-corrosion triazole film, J. Sci. Technol., 2009, 10, 92-99.

7. LJ. Aljinovic, S. Gudic and M. Smith, Inhibition of CuNi10Fe in sea water by sodiumdiethyl-dithiocarbamate: an electrochemical and analytical study, J. Appl. Electrochem., 2000, 30, 973-979. doi: 10.1023/A:1004074405514

8. A. Dafali, B. Hammouti, A. Aouniti, R. Mokhlisse, S. Kertit and K. Elkacemi, 2Mercapto-1-methylimidazole as corrosion inhibitor of copper in aerated $3 \% \mathrm{NaCl}$ solution, Ann. Chim. (Cachan, Fr.), 2000, 25, 437-446. doi: 10.1016/S01519107(00)80019-7

9. I. Majumdar, F. D'souza and N.B. Bhosle, Microbial exopolysaccharides: Effect on corrosion and partial chemical characterization, J. Indian Inst. Sci., 1999, 79, 539-550.

10. S. Rajendran, B.V. Apparao and N. Palaniswamy, Corrosion inhibition by phosphonic acid - Zn systems for mild steel in chloride medium, Anti-Corros. Methods Mater., 2000, 47, 359-365. doi: $10.1108 / 00035590010361764$

11. R.S. Dubey and Y. Potdar, Corrosion inhibition of 304 stainless steel in sodium chloride by ciprofloxacin and norfloxacin, Indian J. Chem. Technol., 2009, 16, 334-338.

12. F.O. Aramide, Corrosion inhibition of AISI/SAE Steel in a marine environment, Leonardo J. Sci., 2009, 15, 47-52.

13. M.R. Laamari, A. Derja, J. Benzakour and M. Berraho, Calcium monofluorophosphate: a new class of corrosion inhibitors in $\mathrm{NaCl}$ medium, J. Electroanal. Chem., 2004, 569, 1-6. doi: 10.1016/j.jelechem.2003.12.045

14. A.T. Ozyilmaz, M. Erbil and B. Yazici, The influence of polyaniline (PANI) top coat on corrosion behavior of nickel plated copper, Appl. Surf. Sci., 2005, 252, 2092-2100. doi: $\underline{10.1016 / j . a p s u s c .2005 .04 .001}$ 
15. A. Aballe, M. Bethencourt, F.J. Botana, M. Marcos and R.M. Osuna, Electrochemical noise applied to the study of the inhibition effect of $\mathrm{CeCl}_{3}$ on the corrosion behaviour of Al-Mg alloy AA5083 in sea water, Electrochim. Acta, 2002, 47, no. 9, 1415-1422. doi: 10.1016/S0013-4686(01)00871-4

16. K. Aramaki, Cerium (III) chloride and sodium octylthiopropionate as an effective inhibitor mixture for zinc corrosion, Corros. Sci., 2002, 44, no. 6, 1361-1374. doi: 10.1016/S0010-938X(01)00116-0

17. P.D. Rani and S. Selvaraj, Inhibitive action of Vitis vinifera (Grape) on copper and brass in natural sea water environment, Rasayan J. Chem., 2010, 3, no. 3, 473-482.

18. P.D. Rani and S. Selvaraj, Emblica Officinalis (OMLA) leaves extract as corrosion inhibitor for copper and its alloy $(\mathrm{Cu}-27 \mathrm{Zn})$ in natural sea water, Arch. Appl. Sci. Res., 2010, 2, no. 6, 140-150.

19. S. Rajendran, M.K. Devi, A.P.P. Regis, A.J. Amalraj, J. Jeyasundari and M. Manivannan, Electroplating using environmental friendly garlic extract, A case study, Zast. Mater., 2009, 50, 131-140.

20. S. Rajendran, P. Chitradevi, S. Johnmary, A. Krishnaveni, S. Kanchana, L. Christy, R. Nagalakshmi, and B. Narayanasamy, Corrosion behaviour of SS 316L in artificial saliva in presence of electral, Zast. Mater., 2010, 51, 149-158.

21. S. Rajendran, M. Agasta, R.B. Devi, B.S. Devi, K. Rajam and J. Jeyasundari, Corrosion inhibition by an aqueous extract of Henna leaves (Lawsonia Inermis L), Zast. Mater., 2009, 50, 77-84.

22. A.C.C. Mary, S. Rajendran and J. Jeyasundari, Influence of Coffee on the corrosion resistance of SS 316L, Ni-Ti alloy and thermoactive alloy in artificial saliva, Eur. Chem. Bull., 2017, 6, 232-237. doi: 10.17628/ecb.2017.6.232-237

23. V. Sribharathy, S. Rajendran, P. Rengan and R. Nagalakshmi, Corrosion Inhibition By An Aqueous Extract Of Aleovera (L) Burm F. (Liliaceae), Eur. Chem. Bull., 2013, 2, 471-476. doi: 10.17628/ecb.2013.2.471-476

24. R. Epshiba, A.P.P. Regis and S. Rajendran, Inhibition of Corrosion of Carbon Steel In A Well Water By Sodium Molybdate- $\mathrm{Zn}^{2+}$ System, Int. J. Nano Corros. Sci. Eng., 2014, 1, $1-11$.

25. N. Kavitha and P. Manjula, Corrosion Inhibition of Water Hyacinth Leaves, $\mathrm{Zn}^{2+}$ and TSC on Mild Steel in neutral aqueous medium, Int. J. Nano Corros. Sci. Eng., 2014, 1, $31-38$.

26. R. Nagalakshmi, L. Nagarajan, R.J. Rathish, S.S. Prabha, N. Vijaya, J. Jeyasundari and S. Rajendran, Corrosion Resistance Of SS3161 In Artificial Urine In Presence Of DGlucose, Int. J. Nano Corros. Sci. Eng., 2014, 1, 39-49.

27. J.A. Thangakani, S. Rajendran, J. Sathiabama, R.M. Joany, R.J. Rathis and S.S. Prabha, Inhibition Of Corrosion Of Carbon Steel In Aqueous Solution Containing Low Chloride Ion By Glycine - $\mathrm{Zn}^{2+}$ System, Int. J. Nano Corros. Sci. Eng., 2014, 1, 50-62.

28. S. Gowri, J. Sathiyabama, S. Rajendran and J.A. Thangakani, J. Chem., Biol. Phys. Sci., 2012, 2, 2223. 
29. A. Nithya, P. Shanthy, N. Vijaya, R.J. Rathish, S.S. Prabha, R.M. Joany and S. Rajendran, Int. J. Nano Corr. Sci. Eng., 2015, $2,1$.

30. A.C.C. Mary, S. Rajendran, H. Al-Hashem, R.J. Rathish, T. Umasankareswari and J. Jeyasundari, Int. J. Nano Corr. Sci. Eng., 2015, 1, 42.

31. A. Anandan, S. Rajendran, J. Sathiyabama and D. Sathiyaraj, Influence of some tablets on corrosion resistance of orthodontic wire made of SS 316L alloy in artificial saliva, Int. J. Corros. Scale Inhib., 2017, 6, no. 2, 132-141. doi: 10.17675/2305-6894-2017-6$\underline{2-3}$

32. C.O. Akalezi, C.E. Ogukwe, E.A. Ejele and E.E. Oguzie, Mild steel protection in acidic media using Mucuna pruriens seed extract, Int. J. Corros. Scale Inhib., 2016, 5, no. 2, 132-146. doi: 10.17675/2305-6894-2016-5-2-3

33. T.A. Onat, D. Yiğit, H. Nazır, M. Güllü and G. Dönmez, Biocorrosion inhibition effect of 2-aminopyrimidine derivativeson SRB, Int. J. Corros. Scale Inhib., 2016, 5, no. 3, 273-281. doi: 10.17675/2305-6894-2016-5-3-7

34. A.S. Fouda, M.A. El-Morsy, A.A. El-Barbary and L.E. Lamloum, Study on corrosion inhibition efficiency of some quinazoline derivatives on stainless steel 304 in hydrochloric acid solutions, Int. J. Corros. Scale Inhib., 2016, 5, no. 2, 112-131. doi: 10.17675/2305-6894-2016-5-2-2

35. V.I. Vigdorovich, L.E. Tsygankova, E.D. Tanygina, A.Yu. Tanygin and N.V. Shel, Preservativematerials basedon vegetable oils for steel protection against atmospheric corrosion. I. Colza oil, Int. J. Corros. Scale Inhib., 2016, 5, no. 1, 59-65. doi: 10.17675/2305-6894-2016-5-1-5

36. P.N. Devi, J. Sathiyabama and S. Rajendran, Study of surface morphology and inhibition efficiency of mild steel in simulated concrete pore solution by lactic acid- $\mathrm{Zn}^{2+}$ system, Int. J. Corros. Scale Inhib., 2017, 6, no. 1, 18-31. doi: 10.17675/2305-6894-2017-6-1$\underline{2}$ 